\title{
Fate of Chemical Warfare Agents and Toxic Industrial Chemicals in
}

\section{Landfills: Supporting Information}

\author{
Shannon L. Bartelt-Hunt, Morton A. Barlaz ' Detlef R.U. Knappe, and Peter Kjeldsen
}

*Corresponding Author. Department of Civil, Construction, and Environmental Engineering, Campus Box 7908, North Carolina State University, Raleigh, NC 27695-7908; Tel. (919) 5157676, Fax (919) 515-7908, barlaz@eos.ncsu.edu

Summary: chemical agent classification, environmental fate of chemical agents, physicalchemical property data for additional TICs, CWAs and their hydrolysates, description of MOCLA and derivation of liner diffusion term, rationale for MOCLA input parameter selection, ranges of $\mathrm{K}_{\mathrm{H}}$ and $\log \mathrm{K}_{\mathrm{ow}}$ for uncertainty analyses, effect of biodegradation and climate on contaminant fate. 
Chemical Agent Classification. Blister agents include sulfur mustard (HD), nitrogen mustard (HN-2), lewisite (L), ethyldichloroarsine (ED), and phosgene oxime (CX). Exposure to these agents damages the respiratory tract when inhaled and causes vomiting and diarrhea when absorbed (1). Most blood agents are cyanide-containing compounds. They poison the cytochrome oxidase system, resulting in a lack of cell respiration and the normal transfer of oxygen from the blood to body tissues (2). Nerve agents are highly toxic with a lethal concentration $\left(\mathrm{LD}_{50}\right)$ of approximately $0.1 \mathrm{mg} / \mathrm{kg}(3)$. The toxicity of nerve agents arises from their ability to irreversibly inhibit acetylcholinesterase, an enzyme involved in the proper functioning of nerves and muscles (1). Nerve agents include tabun (GA), sarin (GB), soman (GD), GE, cyclohexyl sarin (GF), amiton (VG), VM and VX.

Environmental Fate of Chemical Agents. In landfills, the behavior of organic contaminants is influenced by the combined effects of biodegradation, sorption, transport in the gas and/or liquid phases (i.e., volatilization and leaching) and abiotic transformation, such as hydrolysis (4-8). Many CWAs hydrolyze in aqueous systems with half-lives on the order of minutes to days. A hydrolysis half-life of $8.5 \mathrm{~min}$ has been reported for HD in aqueous systems (9); however, the overall rate of HD disappearance is often limited by the slow rate of HD dissolution from a nonaqueous phase into water. Also, hydrolysis products can coat the surface of HD droplets and retard HD dissolution (10). Both its hydrophobicity and the formation of hydrolysis products make non-aqueous-phase HD fairly persistent in the environment. HD hydrolysis can occur via two pathways that are dependent on water availability, but the dominant products of either pathway are thiodiglycol (TDG) and hydrochloric acid (10). Like HD, the principal environmental fate pathway of $\mathrm{HN}-2$ is hydrolysis. A hydrolysis half-life of $11 \mathrm{~h}$ has been calculated for $\mathrm{HN}-2$ at $25^{\circ} \mathrm{C}$ in a $66.7 \%$ acetone-water solution (11). The primary hydrolysate is 
the hydrochloride form of 2-(2-chloroethyl) methylamino ethanol, which is highly toxic by the oral route in rats and mice (10).

Hydrolysis rates of nerve agents are slower than those of HD or HN-2, with half-lives of 14$28 \mathrm{~h}$ at $\mathrm{pH} 7$ and $25^{\circ} \mathrm{C}, 39 \mathrm{~h}$ at $\mathrm{pH} 7.5$ and $25^{\circ} \mathrm{C}$, and $60 \mathrm{~h}$ at $\mathrm{pH} 6$ and $25^{\circ} \mathrm{C}$ for $\mathrm{GA}, \mathrm{GB}$, and GD, respectively $(10,12)$. The primary product of GA hydrolysis is phosphoric acid and the primary product of GB and GD hydrolysis is methylphosphonic acid (MPA) (3, 13). Hydrolysis of VX is slower than that of the G-agents, with a reported half-life of $17-42 \mathrm{~d}$ at $25^{\circ} \mathrm{C}$ and $\mathrm{pH} 7$ (14). The hydrolysis products are $\mathrm{pH}$-dependent, but S-(2-diisopropylaminoethyl) methyl phosphonothioate (EA2192) and ethanol are formed at pH 7 to 10 (3). EA2192 has anticholinesterase activity that is similar to that of VX (10).

The rate of CWA hydrolysis is dependent on such factors as temperature, $\mathrm{pH}$ and water quality. Hydrolysis rates increase with increasing temperature. For example, the rate of HD hydrolysis at $70^{\circ} \mathrm{C}$ was 28 times that at $30^{\circ} \mathrm{C}(15)$. For GB at $\mathrm{pH} 7$, hydrolysis half-lives of 2650 $\mathrm{h}$ and $39-41 \mathrm{~h}$ were reported at $0^{\circ} \mathrm{C}$ and $25^{\circ} \mathrm{C}$, respectively (14). The effect of $\mathrm{pH}$ on CWA hydrolysis varies; e.g. GD hydrolysis is acid-catalyzed with half-lives of 3, 50, and $60 \mathrm{hr}$ at $\mathrm{pH} \mathrm{2,}$ 7.6, and 9, respectively (14), while VX hydrolysis is base-catalyzed with half-lives of 2400, 17

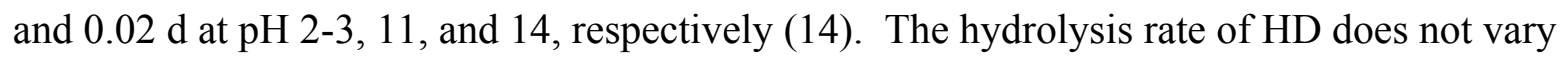
between $\mathrm{pH} 5$ and 10 (14), which covers the typical pH range for landfill leachate. High chloride ion concentrations can inhibit HD hydrolysis (16), an observation that is likely important in a landfill environment because of the relatively high chloride concentrations in landfill leachates (17). GA and GB hydrolysis rates were enhanced by the presence of dissolved oxygen and cations such as $\mathrm{Cu}^{2+}, \mathrm{Ca}^{2+}, \mathrm{Al}^{3+}, \mathrm{Mg}^{2+}$, and $\mathrm{Mn}^{2+}(14)$. 
Sorption to organic waste constituents retards the transport of organic contaminants in landfills. Municipal solid waste (MSW) is $\sim 50 \%$ cellulose, $10-15 \%$ hemicellulose, and $15-20 \%$ lignin $(18,19)$. In addition, MSW contains $\sim 10 \%$ plastics. In terms of elemental composition, MSW is about $50 \%$ organic carbon $(18,19)$; therefore, a large fraction of MSW represents a sorbent for organic compounds. For many MSW constituents, sorption of neutral organic contaminants can be described by a partitioning model $(4,8)$, and the sorption capacity of an organic MSW constituent increases with increasing sorbent hydrophobicity (8) and sorbate octanol-water partition coefficient, $\log \mathrm{K}_{\mathrm{ow}}$ (4). For ionizable CWAs, it was assumed that only the neutral species sorbs appreciably; for octanol-water systems, this assumption is valid up to several $\mathrm{pH}$ units above the $\mathrm{pK}_{\mathrm{a}}$ of organic acids (20).

Although biodegradation of CWAs is theoretically possible, biodegradation of many CWAs has not been observed due to their toxicity (10). Assuming that CWA-exposed building debris will be decontaminated prior to disposal, some anaerobic degradation may occur in landfills if CWAs are present at low aqueous-phase concentrations. It is more likely that biodegradation of CWA hydrolysates will occur because CWAs hydrolyze rapidly and hydrolysates generally have reduced toxicity relative to the original agents. Only one study was identified that investigated the anaerobic biodegradability of CWA hydrolysates. Skylar et al. (21) reported $42 \%$ degradation of TDG (HD hydrolysate) by an anaerobic sludge inoculum after $185 \mathrm{~d}$. The addition of co-substrates (volatile fatty acids, glucose) reduced the TDG half-life to less than 30 d.

Physical-Chemical Data for additional CWAs. Evaluation of the transport of a number of additional CWAs was performed using MOCLA. A complete list of all CWAs evaluated is 
presented in Table S1. Physical-chemical property data for CWAs and TICs not presented in Table 2 of the manuscript are given in Table S2. 


\section{Description of MOCLA model and derivation of liner diffusion term.}

Box S1. Equations of the original MOCLA model

The total concentration of the chemical $\mathrm{C}_{\mathrm{T}}\left(\mathrm{g}\right.$ chemical $\mathrm{m}^{-3}$ landfill $)$ at any time, $\mathrm{t}$, is calculated with:

$$
C_{T}=C_{T, 0} \exp \left(-\frac{k}{R_{a}} \cdot t\right)
$$

where:

$C_{T, 0}$ is the initial total concentration of the chemical (g chemical $\mathrm{m}^{-3}$ landfill) at $t=0$

$$
k=q_{a}^{\prime}+\frac{N}{H K_{H}}+\frac{\varepsilon_{w} \lambda}{K_{H}}
$$

$R_{a}$ is the retardation factor:

$$
R_{a}=\frac{\rho_{b} \cdot f_{o c} \cdot K_{o c}+\varepsilon_{w}}{K_{H}}+\varepsilon_{a}
$$

$q_{a}^{\prime}$ is the specific gas flow (see Box S2)

$N$ is the annual net precipitation $\left(\mathrm{m} \mathrm{yr}^{-1}\right)$

$H$ is the depth of waste (m)

$K_{H}$ is the dimensionless Henry's Law constant

$f_{o c}$ is the fraction of organic carbon in the dry waste

$K_{o c}$ is the distribution coefficient between solid organic carbon and water (see Box S2)

$\lambda$ is the first order transformation constant $\left(\mathrm{yr}^{-1}\right)$

$\rho_{b}$ is the dry bulk density of the dry waste in the landfill (tonne dry waste $\mathrm{m}^{-3}$ landfill)

$\varepsilon_{\mathrm{W}}$ is the volumetric moisture content in the landfill $\left(\mathrm{m}^{3}\right.$ water $\mathrm{m}^{-3}$ landfill)

$\varepsilon_{\mathrm{a}}$ is the volumetric air content in the landfill $\left(\mathrm{m}^{3}\right.$ air $\mathrm{m}^{-3}$ landfill $)$

The transport of chemicals via landfill gas $\left(\mathrm{F}_{\mathrm{a}}\right)$, diffusion through the top cover $\left(\mathrm{F}_{\mathrm{gd}}\right)$ and leachate $\left(\mathrm{F}_{\mathrm{w}}\right)$ is calculated with the following equations:

$$
F_{a}=\frac{V q_{a}}{R_{a}} \cdot C_{T}(t) \quad(\mathrm{S} 4) \quad F_{g d}(t)=\frac{Q_{D}}{R_{a}} \cdot C_{T}(t) \quad(\mathrm{S} 5) \quad F_{w}(t)=\frac{N A}{K_{H} R_{a}} \cdot C_{T}(t)
$$

where $Q_{D}=V \cdot q_{D}($ see Box $S 2)$ 
Box S2. Additional MOCLA equations.

The sum of the specific gas production rate and diffusional 'flow' is combined into a specific gas flow $\mathrm{q}_{\mathrm{a}}$ :

$$
\mathrm{q}_{\mathrm{a}}{ }^{\prime}=\mathrm{q}_{\mathrm{a}}+\mathrm{q}_{\mathrm{D}}
$$

where $\mathrm{q}_{\mathrm{a}}$ is the specific gas production rate $\left(\mathrm{m}^{-3}\right.$ landfill gas $\mathrm{m}^{-3}$ waste $\left.\mathrm{yr}^{-1}\right)$

and $\mathrm{q}_{\mathrm{D}}$, the diffusional 'flow' is calculated from:

$$
q_{D}=\frac{\varepsilon_{a, S C}^{10 / 3} D_{a i r} A}{\varepsilon_{S C}^{2} L V}
$$

$\mathrm{D}_{\text {air }}$ is the molecular diffusion coefficient of the chemical in air $\left(\mathrm{m}^{2} \mathrm{yr}^{-1}\right)$

$\varepsilon_{\mathrm{SC}}$ is the total porosity of the soil cover $\left(\mathrm{m}^{3}\right.$ pore space $\mathrm{m}^{-3}$ soil cover)

$\varepsilon_{\mathrm{a}, \mathrm{SC}}$ is the volumetric content of air in the soil cover $\left(\mathrm{m}^{3}\right.$ air $\mathrm{m}^{-3}$ soil cover $)$

$\mathrm{L}$ is the thickness of the soil cover $(\mathrm{m})$

A is the surface area of the landfill $\left(\mathrm{m}^{2}\right)$

$\mathrm{V}$ is the total volume of waste in the landfill $\left(\mathrm{m}^{3}\right)$

For neutral compounds, $\mathrm{K}_{\mathrm{oc}}$, the distribution coefficient between solid organic carbon and water is calculated from:

$$
\log \mathrm{K}_{\mathrm{oc}}=0.72 \cdot \log \mathrm{K}_{\mathrm{ow}}+0.49
$$

where $\mathrm{K}_{\mathrm{ow}}$ is the octanol-water distribution coefficient (dimensionless)

For organic bases (tertiary amines), $\mathrm{K}_{\mathrm{oc}}(\mathrm{pH})$, the $\mathrm{pH}$-dependent distribution coefficient is calculated from (20):

$$
\mathrm{K}_{\mathrm{oc}}(\mathrm{pH})=(1-\alpha)^{\cdot} \mathrm{K}_{\mathrm{oc}}
$$

where $\mathrm{K}_{\mathrm{oc}}$ is the distribution coefficient for the neutral compound and $\alpha$, the fraction of the non-dissociated (cationic) species, is calculated from:

$$
\alpha=1 /\left(1+10^{(\mathrm{pH}-\mathrm{pKa})}\right)
$$


Box S3. Incorporation of liner diffusion term into MOCLA.

In addition to the processes originally modeled by MOCLA, a term was incorporated to evaluate diffusion through the composite liner.

The diffusive flux through the liner can be expressed by:

$$
J_{D i f f}=D \frac{\partial C}{\partial x}
$$

where:

$\mathrm{J}_{\text {Diff }}$ is the diffusive flux through the liner $\left(\mathrm{g} \mathrm{m}^{-2} \mathrm{yr}^{-1}\right)$

$\mathrm{D}$ is the diffusion coefficient in the soil cover

$\partial \mathrm{C} / \partial \mathrm{x}$ is the concentration gradient $\left(\mathrm{g} \mathrm{m}^{-4}\right)$

The diffusion coefficient $(D)$ in eqn. S12 is the effective diffusion coefficient for the composite geomembrane/clay liner. It was assumed that the geomembrane layer does not impede the diffusive flux through the composite liner as volatile organic compounds have been shown to penetrate geomembranes at an appreciable rate (22). Therefore, the diffusion coefficient for the composite liner was represented by the effective diffusion coefficient for the clay layer.

Since clay liners are typically compacted at a moisture content less than saturation, diffusion will occur through both the air-filled and water-filled pore spaces within the clay. In a porous medium, the effective diffusion coefficient for each phase $\left(D^{*}\right.$ air or $\left.D^{*}{ }_{\text {water }}\right)$ is calculated from the molecular diffusivity of the compound in air or water $\left(D_{\text {air }}\right.$ or $\left.D_{\text {water }}\right)$, the total porosity of the clay liner $\left(\varepsilon_{\mathrm{L}}\right)$, and the air- or water-filled porosity of the liner $\left(\varepsilon_{\mathrm{a}, \mathrm{L}}\right.$ or $\left.\varepsilon_{\mathrm{w}, \mathrm{L}}\right)$. One commonly-used expression is the Millington equation, which relates the effective diffusion coefficient to the molecular diffusion coefficient by (23):

$$
D_{a i r}^{*}=D_{a i r} \frac{\varepsilon_{a, L}^{3.33}}{\varepsilon_{L}^{2}}
$$

and

$$
D_{\text {water }}^{*}=D_{\text {water }} \frac{\varepsilon_{w, L}^{3.33}}{\varepsilon_{L}{ }^{2}}
$$


Box S3 (continued). Incorporation of liner diffusion term into MOCLA.

Combining expressions S13 and S14 along with Henry's Law results in the following equation for the diffusive flux through the liner (24):

$$
J_{\text {Diff }}=\left(D_{\text {air }} \frac{\varepsilon_{a, L}^{3.33}}{\varepsilon_{L}^{2}}+\frac{D_{\text {water }}}{K_{H}} \frac{\varepsilon_{w, L}^{3.33}}{\varepsilon_{L}^{2}}\right) \frac{\partial C_{a}}{\partial x}
$$

where $\mathrm{C}_{\mathrm{a}}$ is equal to the gas-phase concentration of the contaminant.

If it is assumed that the concentration of the contaminant of interest in the aquifer beneath the liner is equal to zero, then the sink due to diffusion through the composite liner may be written as:

$$
S_{\text {Diff }}=\left(D_{\text {air }} \frac{\varepsilon_{a, L}^{3.33}}{\varepsilon_{L}^{2}}+\frac{D_{\text {water }}}{K_{H}} \frac{\varepsilon_{w, L}^{3.33}}{\varepsilon_{L}^{2}}\right) A \frac{C_{a}}{L_{\text {liner }}}
$$

where:

$S_{\text {Diff }}$ is the sink due to diffusion through the liner $\left(\mathrm{g} \mathrm{yr}^{-1}\right)$

$L_{\text {liner }}$ is the thickness of the clay layer of the composite liner (m)

$S_{D i f f}$ can be simplified to:

$$
S_{\text {Diff }}=Q_{D, \text { liner }} C_{a}
$$

where:

$$
Q_{D, \text { Liner }}=\frac{D_{\text {eff }} A}{L_{\text {liner }}}
$$

and

$$
D_{\text {eff }}=D_{\text {air }} \frac{\varepsilon_{a, L}^{3.33}}{\varepsilon_{L}^{2}}+\frac{D_{w a t e r}}{K_{H}} \frac{\varepsilon_{w, L}^{3.33}}{\varepsilon_{L}^{2}}
$$

Because literature values for $\varepsilon_{\mathrm{a}, \mathrm{SC}}$ and $\varepsilon_{\mathrm{a}, \mathrm{L}}$ were not available, these terms were calculated as:

$$
\begin{aligned}
& \varepsilon_{a, S C}=\max \left(0, \varepsilon_{s c}-\rho_{b, s c} \cdot M C_{s c}\right) \\
& \text { and } \\
& \varepsilon_{a, L}=\max \left(0, \varepsilon_{L}-\rho_{b, L} \cdot M C_{L}\right)
\end{aligned}
$$

where:

$\varepsilon_{\mathrm{sc}}$ and $\varepsilon_{\mathrm{L}}$ are the total porosity of the soil cover and liner $\left(\mathrm{m}^{3}\right.$ voids $\mathrm{m}^{-3}$ cover or liner) $\rho_{\mathrm{b}, \mathrm{SC}}$ and $\rho_{\mathrm{b}, \mathrm{L}}$ are the dry bulk density of the soil cover and liner (g soil $\mathrm{m}^{-3}$ cover or liner) $\mathrm{MC}_{\mathrm{SC}}$ and $\mathrm{MC}_{\mathrm{L}}$ are the gravimetric moisture content of the soil cover and liner (\%) 
Box S3 (continued). Incorporation of liner diffusion term into MOCLA.

Including the diffusive flux term into the original MOCLA mass balance equation gives:

$$
\frac{d\left(V C_{T}\right)}{d t}=-\left(S_{a}+S_{g d}+S_{w}+S_{\lambda}+S_{d i f f}\right)
$$

rearranging this expression gives:

$$
\frac{d C_{T}}{d t}=-\left(q_{a}^{\prime}+\frac{N}{H K_{H}}+\frac{\varepsilon_{w} \lambda}{K_{H}}+\frac{Q_{D, \text { liner }}}{V}\right)
$$

if $\mathrm{q}_{\mathrm{D}}$, liner $=\mathrm{Q}_{\mathrm{D} \text {, liner }} / \mathrm{V}$, then a new expression for $\mathrm{k}$ can be written:

$$
k=q_{a}^{\prime}+\frac{N}{H K_{H}}+\frac{\varepsilon_{w} \lambda}{K_{H}}+q_{D, \text { liner }}^{\prime}
$$

Integrating each term on the right-hand side of eqn. S22 gives the expressions for the fate routes. The new expression for fate via liner diffusion is written as:

$$
F_{\text {diff }}=q_{D, \text { liner }}^{\prime}\left(1-\exp \left(-\frac{k}{R_{a}} t\right)\right)
$$




\section{Methodology used to determine MOCLA input parameter values (physical parameters).}

To evaluate the distribution and fate of chemicals in a landfill, data for a number of input parameters describing the landfill design and operation are required. This section describes each parameter and provides an explanation of how parameter values that could be applicable under various disposal scenarios were determined.

Dry bulk density of the waste, $\rho_{b}\left(T \mathrm{~m}^{-3}\right)$. It is assumed that the building debris will be contained for transport and burial and therefore will not be compacted after placement in the landfill. Therefore, the wet bulk density of the building debris will likely be lower than the average value of wet bulk density for compacted waste, which is about $0.76 \mathrm{~T} \mathrm{~m}^{-3}$. The range of wet bulk densities to be used in the bounding calculations was 0.42 to $0.70 \mathrm{~T} \mathrm{~m}^{-3}$, with an average value of $0.55 \mathrm{~T} \mathrm{~m}^{-3}$

The dry bulk density was determined from the wet bulk density and an estimate of the gravimetric moisture content of the waste. If the gravimetric moisture content (MC) of the waste is assumed to be $10-20 \%$ (wet weight basis), then the dry bulk density can be calculated as follows:

Using a design basis of $1 \mathrm{~m}^{3}$ of refuse, the total mass of waste is equal to $0.42 \mathrm{~T}$, which corresponds to the low end of the range. The mass of water in $1 \mathrm{~m}^{3}$ of refuse is equal to 0.42 times 0.20 (highest possible value of MC) or $0.084 \mathrm{~T}$. The total mass of waste minus the mass of water $(0.42-0.084)$ results in the mass of dry refuse which is $0.34 \mathrm{~T}$. Therefore, the low value of the range for dry bulk density is $0.34 \mathrm{~T} \mathrm{~m}^{-3}$. Similarly, the high end of the range is $0.63 \mathrm{~T} \mathrm{~m}^{-3}$. The average value is $0.49 \mathrm{~T} \mathrm{~m}^{-3}$. Volumetric moisture content of the waste, $\varepsilon_{w}\left(m^{3}\right.$ water $\left.m^{-3} L F\right)$. The possible values of volumetric moisture content of the waste can be calculated from the ranges of the wet bulk 
density and the gravimetric moisture content assuming $1 \mathrm{~m}^{3}$ of waste. The lowest value in the range of volumetric moisture contents is calculated at $10 \%$ gravimetric moisture. The mass of water in $1 \mathrm{~m}^{3}$ of waste is $0.42 \mathrm{~T}$ (total mass) times 0.10 (mass of water/total mass) which is 0.042 T. The density of water is $1 \mathrm{~T} \mathrm{~m}^{-3}$, so the volumetric moisture content is equal to $0.042 \mathrm{~m}^{3}$ water $\mathrm{m}^{-3} \mathrm{LF}$. Similarly, the highest value in the range is $0.14 \mathrm{~m}^{3}$ water $\mathrm{m}^{-3} \mathrm{LF}$, which is equivalent to $0.70 \mathrm{~T}$ times 0.20 . The average volumetric moisture content is $0.091 \mathrm{~m}^{3}$ water $\mathrm{m}^{-3} \mathrm{LF}$. Volumetric gas content of the waste, $\varepsilon_{a}\left(\mathrm{~m}^{3}\right.$ air $\left./ \mathrm{m}^{3} \mathrm{LF}\right)$. A range of 0.10 to 0.40 was assumed for the volumetric gas content of the waste. There is very little data on measured values of the effective porosity of waste. Bendz et al. (25) reported a measured value of 0.12 for a waste sample from an operating MSW landfill. Based on the range specified above, the average value for the volumetric gas content of the waste is 0.25 .

Fraction of organic carbon, $f_{o c}$. A range of 0.40 to 0.60 was used for the fraction of organic carbon in the waste. A value of 0.50 was reported for a sample of MSW (26), which will be used as the average value in the bounding calculations.

Height of the waste in the landfill, $H(m)$. The height of waste in the landfill is assumed to vary between 18.3 and $61 \mathrm{~m}$. Based on this range, the average height of waste in the landfill was 39.7 m.

The final two terms required to describe the landfill, infiltration and the gas production rate, are a function of the climate in which the landfill is located. As a result, two sets of values for these parameters were used to represent an arid or a wet climate.

Net precipitation, $N$ (m/year). The net precipitation, or infiltration, was calculated based on data reported in Camobreco et al. (27). For the arid climate scenario, data from sites with less than $0.5 \mathrm{~m} \mathrm{yr}^{-1}$ of total precipitation were used, while the data from sites with greater than or equal to 
$0.5 \mathrm{~m} \mathrm{yr}^{-1}$ were used for the wet climate scenario. For each site, the total precipitation was multiplied by the percentage of precipitation that becomes leachate to determine the net precipitation or infiltration. Using this method, infiltration for the arid climate was found to range from 0.02 to $0.05 \mathrm{~m} \mathrm{yr}^{-1}$ with an average value of $0.04 \mathrm{~m} \mathrm{yr}^{-1}$. Infiltration for the wet climate ranged from 0.04 to $0.32 \mathrm{~m} \mathrm{yr}^{-1}$ with an average of $0.12 \mathrm{~m} \mathrm{yr}^{-1}$. Although the data used to generate these estimates encompassed a variety of different percentages of final cover, it should be noted that modeling a dry (fully capped) landfill is potentially a more realistic scenario than a wet landfill since the building debris will likely be encapsulated and the greatest likelihood for leakage from the containers will occur after the final cover has been placed, when infiltration is minimal.

Gas production rate, $q_{a}\left(m^{3} L F G m^{-3} L F y r^{-1}\right)$. The landfill gas (LFG) production rate can be described by the following equation (28):

$\mathrm{q}_{\mathrm{a}}=2 \mathrm{WL}_{\mathrm{o}} \mathrm{ke}^{-\mathrm{kt}}$

where $\mathrm{W}$ is the mass of refuse, $\mathrm{L}_{\mathrm{o}}$ is a term representing the ultimate volume of methane gas produced per unit of wet waste, and $\mathrm{k}$ is a rate constant $\left(\mathrm{yr}^{-1}\right)$. Equation $\mathrm{S} 24$ assumes a methane concentration of $50 \%$ in LFG.

The mass of refuse (W) is a function of the bulk density of the waste, which as stated above, was assumed to vary from 0.42 to $0.70 \mathrm{~T} \mathrm{~m}^{-3}$, with an average value of $0.55 \mathrm{~T} \mathrm{~m}^{-3}$. Assuming 1 $\mathrm{m}^{3}$ of waste, $\mathrm{W}$ will be equal to $0.55 \mathrm{~T}$. $\mathrm{L}_{\mathrm{o}}$ was assumed to vary between 85 and $170 \mathrm{~L}$ methane $\mathrm{kg}^{-1}$ wet waste. The value of $170 \mathrm{~L}_{\text {methane }} \mathrm{kg}^{-1}$ wet waste is the default used in the New Source Performance Standards of the Clean Air Act amendments (29). For the arid climate scenario, the rate constant $(\mathrm{k})$ was set to $0.02 \mathrm{yr}^{-1}$. For the wet climate scenario, the rate constant (k) was set to $0.05 \mathrm{yr}^{-1}$. For the arid scenario, $\mathrm{q}_{\mathrm{a}}$ was found to range from 1.9 to $3.7 \mathrm{~m}^{3} \mathrm{LFG} \mathrm{m}^{-3}$ 
$\mathrm{LF} \mathrm{yr}^{-1}$ with an average value of $2.8 \mathrm{~m}^{3} \mathrm{LFG} \mathrm{m}^{-3} \mathrm{LF} \mathrm{yr}^{-1}$. For the wet scenario, $\mathrm{q}_{\mathrm{a}}$ was found to

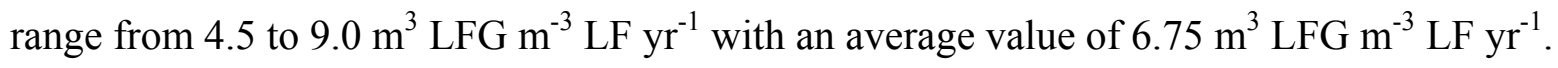
Thickness of cover, $L(m)$. The thickness of the landfill cover was set to $0.45 \mathrm{~m}$ which is the minimum thickness specified by Subtitle D regulation for the thickness of the barrier layer (30). This value was not varied in the bounding calculations.

Total porosity of the soil cover, $\varepsilon_{s c}$ (dimensionless). The total porosity of the soil cover ranged from 0.3 to 0.5 with an average value of 0.4 . A total porosity between 0.3 and 0.5 is common for a wide range of soil types.

Gravimetric moisture content of soil cover $\left(M C_{S C}\right)$. The gravimetric moisture content of the soil cover ranged from 10.3 to $30.8 \%$ (dry weight basis) with an average value of $20.0 \%$ based published data (31).

Dry bulk density of the cover soil, $\rho_{b, S C}\left(\mathrm{~g} \mathrm{~cm}^{-3}\right)$. The dry bulk density of the soil cover ranged from 1.3 to $2.0 \mathrm{~g} \mathrm{~cm}^{-3}$ with an average value of $1.7 \mathrm{~g} \mathrm{~cm}^{-3}$ based on published data (31). It should be noted that the gravimetric moisture content and dry bulk density of the cover soil are not used directly in MOCLA. These parameters are used along with the porosity of the cover soil to calculate the air-filled porosity of the cover soil, which is an input parameter to MOCLA. Liner thickness, $L_{\text {liner }}(m)$. The thickness of the landfill liner was set to $0.6 \mathrm{~m}$, which is the minimum thickness required by EPA Subtitle D regulation (30). The liner thickness was not varied in the bounding calculations.

Total porosity of the liner, $\varepsilon_{L}$ (dimensionless). The total porosity of the liner ranged from 0.3 to 0.5 with an average value of 0.4 . A total porosity between 0.3 and 0.5 is common for a wide range of soil types. 
Gravimetric moisture content of the liner $\left(M C_{L}\right)$. Based on published data (31), the gravimetric moisture content of the liner ranged from 10.3 to $30.8 \%$, with an average value of $20.0 \%$. Dry bulk density of the liner materials, $\rho_{b, L}\left(\mathrm{~g} \mathrm{~cm}^{-3}\right)$. Based on published data (31), the dry bulk density of the liner ranged from 1.3 to $2.0 \mathrm{~g} \mathrm{~cm}^{-3}$ with an average value of $1.7 \mathrm{~g} \mathrm{~cm}^{-3}$ It should be noted that the gravimetric moisture content and dry bulk density of the liner are not used directly in MOCLA. These parameters are used along with the porosity of the liner to calculate the air-filled porosity of the liner, which is an input parameter to MOCLA. 
Table S1. List of Studied CWAs and TICs.

\begin{tabular}{|c|c|c|c|c|}
\hline $\begin{array}{c}\text { Military } \\
\text { Designation }\end{array}$ & Common Name & Chemical Formula & CAS number & Use \\
\hline \hline & Carbon disulfide & $\mathrm{CS}_{2}$ & $75-15-0$ & $\begin{array}{c}\text { Toxic Industrial } \\
\text { Chemical }\end{array}$ \\
\hline $\mathrm{H} / \mathrm{HD}$ & Furan & $\mathrm{C}_{4} \mathrm{H}_{4} \mathrm{O}$ & $110-00-9$ & $\begin{array}{c}\text { Toxic Industrial } \\
\text { Chemical }\end{array}$ \\
\hline $\mathrm{HN}-2$ & Nitrogen Mustard & $\mathrm{C}_{4} \mathrm{H}_{8} \mathrm{Cl}_{2} \mathrm{~S}$ & $505-60-2$ & $\begin{array}{c}\text { Blister } \\
\text { Agent/Vesicant }\end{array}$ \\
\hline L & Lewisite & $\mathrm{C}_{5} \mathrm{H}_{11} \mathrm{Cl}_{2} \mathrm{~N}$ & $51-75-2$ & $\begin{array}{c}\text { Blister } \\
\text { Agent/Vesicant }\end{array}$ \\
\hline ED & Ethyldichloroarsine & $\mathrm{C}_{2} \mathrm{H}_{2} \mathrm{AsCl}_{3}$ & $541-25-3$ & $\begin{array}{c}\text { Blister } \\
\text { Agent/Vesicant }\end{array}$ \\
\hline $\mathrm{CX}$ & Phosgene Oxime & $\mathrm{CHCl}_{5} \mathrm{AsCl}_{2}$ & $598-14-1$ & $\begin{array}{c}\text { Blister } \\
\text { Agent/Vesicant }\end{array}$ \\
\hline GA & Tabun & $\mathrm{C}_{5} \mathrm{H}_{11} \mathrm{~N}_{2} \mathrm{O}_{2} \mathrm{P}$ & $77-81-6$ & $\begin{array}{c}\text { Blister } \\
\text { Agent/Vesicant }\end{array}$ \\
\hline GB & Sarin & $\mathrm{C}_{4} \mathrm{H}_{10} \mathrm{FO}_{2} \mathrm{P}$ & $107-44-8$ & Nerve Agent \\
\hline GD & Soman & $\mathrm{C}_{7} \mathrm{H}_{16} \mathrm{FO}_{2} \mathrm{P}$ & $96-64-0$ & Nerve Agent \\
\hline GE & & $\mathrm{C}_{5} \mathrm{H}_{12} \mathrm{FO}_{2} \mathrm{P}$ & $1189-87-3$ & Nerve Agent \\
\hline GF & Cyclohexyl Sarin & $\mathrm{C}_{7} \mathrm{H}_{14} \mathrm{FO}_{2} \mathrm{P}$ & $329-99-7$ & Nerve Agent \\
\hline VG & Amiton & $\mathrm{C}_{10} \mathrm{H}_{24} \mathrm{NO}_{3} \mathrm{PS}$ & $78-53-5$ & Nerve Agent \\
\hline VM & & $\mathrm{C}_{9} \mathrm{H}_{22} \mathrm{NO}_{2} \mathrm{PS}$ & $21770-86-5$ & Nerve Agent \\
\hline VX & V-gas & $\mathrm{C}_{11} \mathrm{H}_{26} \mathrm{NO}_{2} \mathrm{PS}$ & $50782-69-9$ & Nerve Agent \\
\hline CS & Tear Gas & $\mathrm{C}_{10} \mathrm{H}_{5} \mathrm{ClN}_{2}$ & $2698-41-1$ & Tear Agent \\
\hline
\end{tabular}


Table S2. Physical-chemical property data for additional CWAs, the riot-control agent CS, and carbon disulfide. ${ }^{\text {a }}$

\begin{tabular}{|c|c|c|c|c|c|c|c|c|c|c|}
\hline Chemical & $\begin{array}{c}\text { Carbon } \\
\text { disulfide }\end{array}$ & $\begin{array}{l}\text { Lewisite } \\
(\mathrm{L})\end{array}$ & $\begin{array}{l}\text { Ethyldichloro- } \\
\text { arsine (ED) }\end{array}$ & $\begin{array}{c}\text { Phosgene } \\
\text { oxime (CX) }\end{array}$ & $\begin{array}{l}\text { Tabun } \\
\text { (GA) }\end{array}$ & GE & GF & VG & VM & $\mathrm{CS}$ \\
\hline $\begin{array}{l}\text { Chemical } \\
\text { Formula }\end{array}$ & $\mathrm{CS}_{2}$ & $\mathrm{C}_{2} \mathrm{H}_{2} \mathrm{AsCl}_{3}$ & $\mathrm{C}_{2} \mathrm{H}_{5} \mathrm{AsCl}_{2}$ & $\mathrm{CHCl}_{2} \mathrm{NO}$ & $\mathrm{C}_{5} \mathrm{H}_{11} \mathrm{~N}_{2} \mathrm{O}_{2} \mathrm{P}$ & $\mathrm{C}_{5} \mathrm{H}_{12} \mathrm{FO}_{2} \mathrm{P}$ & $\mathrm{C}_{7} \mathrm{H}_{14} \mathrm{FO}_{2} \mathrm{P}$ & $\mathrm{C}_{10} \mathrm{H}_{24} \mathrm{NO}_{3} \mathrm{PS}$ & $\mathrm{C}_{9} \mathrm{H}_{22} \mathrm{NO}_{2} \mathrm{PS}$ & $\mathrm{C}_{10} \mathrm{H}_{5} \mathrm{ClN}_{2}$ \\
\hline CAS number & $75-15-0$ & $541-25-3$ & 598-14-1 & $1794-86-1$ & $77-81-6$ & $1189-87-3$ & $329-99-7$ & $78-53-5$ & $21770-86-5$ & $2698-41-1$ \\
\hline $\mathrm{MW}\left(\mathrm{g} \mathrm{mol}^{-1}\right)$ & 76.13 & 207.32 & 174.89 & 113.93 & 162.13 & 154.12 & 180.16 & 269.34 & 239.32 & 188.62 \\
\hline b.p. $\left({ }^{\circ} \mathrm{C}\right)$ & 46.2 & 196 & 156 & 129 & 248 & $162^{\mathrm{b}}$ & 228 & $337^{\mathrm{b}}$ & $310^{\mathrm{b}}$ & 310 \\
\hline f.p. $\left({ }^{\circ} \mathrm{C}\right)$ & -110 & -1.2 & -65 & 39 & $-50^{\mathrm{b}}$ & $-52.4^{b}$ & -12 & $<25$ & $54.2^{\mathrm{b}}$ & 95 \\
\hline $\begin{array}{l}\text { Vapor } \\
\text { pressure } \\
(\mathbf{m m} \mathrm{Hg})\end{array}$ & 359 & 0.58 & 2.29 & $24.3\left(50^{\circ} \mathrm{C}\right)$ & 0.057 & $2.3^{\mathrm{b}}$ & 0.09 & $2.7 \times 10^{-4(\mathrm{~b})}$ & $6.1 \times 10^{-4(b)}$ & $3.4 \times 10^{-4}$ \\
\hline $\begin{array}{c}K_{H} \\
\text { (dimensionless) }\end{array}$ & $5.9 \times 10^{-1}$ & $1.1 \times 10^{-2(b)}$ & $2.4 \times 10^{-2(b)}$ & $2.2 \times 10^{-5(\mathrm{~b})}$ & $6.54 \times 10^{-7(\mathrm{~b})}$ & $5.0 \times 10^{-4(\mathrm{~b})}$ & $3.9 \times 10^{-4(\mathrm{~b})}$ & $1.2 \times 10^{-8(b)}$ & $4.5 \times 10^{-8(b)}$ & $4.2 \times 10^{-7(b)}$ \\
\hline $\log K_{\text {ow }}$ & 1.94 & $2.56^{\mathrm{b}}$ & $2.34^{\mathrm{b}}$ & $0.73^{\mathrm{b}}$ & 0.394 & $0.73^{\mathrm{b}}$ & $1.6^{\mathrm{b}}$ & $1.7^{\mathrm{b}}$ & $1.23^{\mathrm{b}}$ & $2.76^{\mathrm{b}}$ \\
\hline $\begin{array}{l}\text { Hydrolysis } \\
\text { half-life (min) }\end{array}$ & $\infty$ & $0.7^{\mathrm{c}}\left(20^{\circ} \mathrm{C}\right)$ & $0.7^{\mathrm{d}}$ & $1.2 \times 10^{5(\mathrm{e})}$ & $\begin{array}{c}840-1,680 \\
\left(25^{\circ} \mathrm{C}\right. \\
\text { neutral pH) }\end{array}$ & $2,400^{\mathrm{f}}$ & $2,400^{\mathrm{f}}$ & $42,480^{\mathrm{g}}$ & $42,480^{\mathrm{g}}$ & 15 \\
\hline $\begin{array}{l}\text { Aqueous } \\
\text { solubility } \\
\left(\mathrm{mg} \mathrm{L}^{-1}\right)\end{array}$ & $\begin{array}{l}2,860 \\
\left(25^{\circ} \mathrm{C}\right)\end{array}$ & $500^{\mathrm{h}}$ & $\begin{array}{c}600^{\mathrm{b}} \\
\left(25^{\circ} \mathrm{C}\right)\end{array}$ & $\begin{array}{l}1.06 \times 10^{4(b)} \\
\left(25^{\circ} \mathrm{C}\right)\end{array}$ & $\begin{array}{l}72,000 \\
\left(20^{\circ} \mathrm{C}\right)\end{array}$ & $\begin{array}{c}1.7 \times 10^{4(\mathrm{~b})} \\
\left(25^{\circ} \mathrm{C}\right)\end{array}$ & $\begin{array}{l}3.7 \times 10^{4} \\
\left(20^{\circ} \mathrm{C}\right)\end{array}$ & $\begin{array}{l}6,600^{\mathrm{b}} \\
\left(25^{\circ} \mathrm{C}\right)\end{array}$ & $\begin{array}{l}2,400^{\mathrm{b}} \\
\left(25^{\circ} \mathrm{C}\right)\end{array}$ & $\begin{array}{c}119^{\mathrm{b}} \\
\left(25^{\circ} \mathrm{C}\right)\end{array}$ \\
\hline $\begin{array}{l}\text { Diffusion } \\
\text { coefficient in } \\
\text { air }\left(\mathrm{cm}^{2} \sec ^{-1}\right)^{i} \\
\text { Diffusion }\end{array}$ & 0.117 & 0.080 & 0.083 & 0.101 & 0.071 & 0.072 & 0.066 & 0.052 & 0.055 & 0.067 \\
\hline $\begin{array}{c}\text { coefficient in } \\
\text { water } \\
\left(\mathrm{cm}^{2} \sec ^{-1}\right)^{\mathrm{j}}\end{array}$ & $1.4 \times 10^{-5}$ & $9.7 \times 10^{-6}$ & $9.7 \times 10^{-6}$ & $1.3 \times 10^{-5}$ & $8.2 \times 10^{-6}$ & $8.0 \times 10^{-6}$ & $7.5 \times 10^{-6}$ & $5.8 \times 10^{-6}$ & $6.2 \times 10^{-6}$ & $8.1 \times 10^{-6}$ \\
\hline $\mathbf{p K} \mathbf{K}_{\mathrm{a}}$ & - & - & - & $7^{\mathrm{k}}(\mathrm{N}-\mathrm{OH})$ & $\begin{array}{c}2.33^{1} \\
\text { (tertiary } \\
\text { amine) }\end{array}$ & - & - & $9^{\mathrm{m}}$ & $9^{\mathrm{m}}$ & - \\
\hline $\begin{array}{l}{ }^{\text {a }} \text { Data compiled fro } \\
\text { half-life for ED est } \\
\text { hydrolysis half-live } \\
\text { Lee equation (42); } \\
\text { Chem-Silico softw }\end{array}$ & $\begin{array}{l}\text { he foll } \\
\text { ed to } \\
\text { GA, } \\
\text { imatec } \\
\text { ackag }\end{array}$ & $\begin{array}{l}\text { g sources: ( } \\
\text { ual to that o } \\
\text { nd GD; }{ }^{\mathrm{g}} \mathrm{Hy} \\
\mathrm{g} \text { Hayduk-I }\end{array}$ & $\begin{array}{l}-39) ;{ }^{b} \text { Estim } \\
\text { sed on struct } \\
\text { sis half-life } \\
\text { equation ( } 4 \\
\text { ad VM estim }\end{array}$ & $\begin{array}{l}\text { vith EPISuit } \\
\text { milarity; }{ }^{\mathrm{e}} \mathrm{H} \\
\text { ted to be equ } \\
\mathrm{K}_{\mathrm{a}} \text { for CX es } \\
\text { o be equival }\end{array}$ & $\begin{array}{l}3.12(40) ;{ }^{\mathrm{c}} \mathrm{H} \\
\text { life calculate } \\
\text { o that of VX } \\
\text { ated from a r } \\
\text { to that of VX }\end{array}$ & $\begin{array}{l}\text { lysis rate } \\
\text { ed on } 5 \% \\
d \text { on struc } \\
\text { of calcul } \\
V \text { is mole }\end{array}$ & $\begin{array}{l}\text { ted to be } \\
\text { pearance a } \\
\text { imilarity; } \\
\text { K }_{\text {a values } \mathrm{f}} \\
\text { veight, b.p }\end{array}$ & 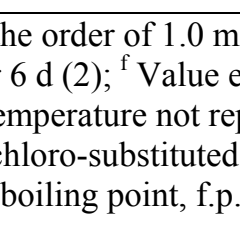 & $\begin{array}{l}-1 \text { at } 20^{\circ} \mathrm{C}(41) \\
\text { imated by ave } \\
\text { rted; }{ }^{\mathrm{i}} \text { Estimat } \\
\text { ximes }(43) ;{ }^{1} \mathrm{H} \\
\text { freezing poir }\end{array}$ & $\begin{array}{l}\text { Hydrolysis } \\
\text { ging } \\
\text { using Wilke- } \\
\text { imated using } \\
\mathrm{K}_{\mathrm{H}} \text { is the }\end{array}$ \\
\hline
\end{tabular}


Table S3. Henry's law constant ranges for organic compounds originally modeled in MOCLA.

\begin{tabular}{|c|c|c|c|c|c|}
\hline \multirow[t]{2}{*}{ Chemical } & \multicolumn{5}{|c|}{$K_{H}$ (dimensionless) } \\
\hline & low & $\begin{array}{c}\text { MOCLA } \\
\text { (accepted) }\end{array}$ & high & $\begin{array}{c}\% \text { difference } \\
\text { (low) }\end{array}$ & $\begin{array}{c}\% \text { difference } \\
\text { (high) }\end{array}$ \\
\hline Benzene & $2.20 \mathrm{E}-01$ & $2.20 \mathrm{E}-01$ & $2.99 \mathrm{E}-01$ & 0.0 & 35.8 \\
\hline Toluene & $2.09 \mathrm{E}-01$ & $2.70 \mathrm{E}-01$ & 3.33E-01 & 22.6 & 23.3 \\
\hline Ethylbenzene & $2.70 \mathrm{E}-01$ & $3.20 \mathrm{E}-01$ & 4.04E-01 & 15.6 & 26.3 \\
\hline Xylene (o) & $1.76 \mathrm{E}-01$ & $2.20 \mathrm{E}-01$ & $3.98 \mathrm{E}-01$ & 20.0 & 80.7 \\
\hline Xylene $(\mathrm{m} / \mathrm{p})$ & $2.04 \mathrm{E}-01$ & $2.80 \mathrm{E}-01$ & $4.50 \mathrm{E}-01$ & 27.1 & 60.7 \\
\hline 1, 3, 5 Trimethylbenzene & $2.42 \mathrm{E}-01$ & $3.40 \mathrm{E}-01$ & $5.89 \mathrm{E}-01$ & 28.8 & 73.2 \\
\hline Phenol & $1.61 \mathrm{E}-05$ & $1.10 \mathrm{E}-05$ & 4.37E-04 & 46.4 & 3870.0 \\
\hline Cresol, (o) & $2.83 \mathrm{E}-05$ & $5.00 \mathrm{E}-05$ & $1.15 \mathrm{E}-04$ & 43.5 & 129.2 \\
\hline 2,4 - Dimethylphenol & $2.79 \mathrm{E}-05$ & $2.70 \mathrm{E}-04$ & $6.95 \mathrm{E}-04$ & 89.7 & 157.4 \\
\hline 1,2-Dichlorobenzene & 4.92E-02 & $8.00 \mathrm{E}-02$ & $1.51 \mathrm{E}-01$ & 38.5 & 89.2 \\
\hline 1,4-Dichlorobenzene & $6.46 \mathrm{E}-02$ & $1.00 \mathrm{E}-01$ & $1.82 \mathrm{E}-01$ & 35.4 & 82.0 \\
\hline 2-Chlorophenol & $2.74 \mathrm{E}-04$ & $3.40 \mathrm{E}-04$ & $4.30 \mathrm{E}-04$ & 19.3 & 26.4 \\
\hline 2,4 - Dichlorophenol & 4.44E-05 & $2.70 \mathrm{E}-04$ & $1.76 \mathrm{E}-04$ & 83.6 & 35.0 \\
\hline Naphthalene & $1.18 \mathrm{E}-02$ & $1.70 \mathrm{E}-02$ & $5.00 \mathrm{E}-02$ & 30.7 & 194.3 \\
\hline 1 - Methylnaphthalene & $6.46 \mathrm{E}-03$ & $1.60 \mathrm{E}-02$ & $2.50 \mathrm{E}-02$ & 59.6 & 56.4 \\
\hline Flourene & $2.04 \mathrm{E}-03$ & $4.00 \mathrm{E}-03$ & $4.80 \mathrm{E}-03$ & 48.9 & 20.1 \\
\hline Anthracene & $7.91 \mathrm{E}-04$ & $2.00 \mathrm{E}-03$ & $2.95 \mathrm{E}-02$ & 60.4 & 1373.1 \\
\hline n-Hexane & $2.04 \mathrm{E}+01$ & $5.60 \mathrm{E}+01$ & $7.67 \mathrm{E}+01$ & 63.5 & 36.9 \\
\hline n-Heptane & $2.95 \mathrm{E}+01$ & $8.10 \mathrm{E}+01$ & $1.10 \mathrm{E}+02$ & 63.6 & 36.2 \\
\hline n-Octane & $4.47 \mathrm{E}+01$ & $1.20 \mathrm{E}+02$ & $2.02 \mathrm{E}+02$ & 62.8 & 68.0 \\
\hline n-Nonane & $1.69 \mathrm{E}+01$ & $2.00 \mathrm{E}+02$ & $2.43 \mathrm{E}+02$ & 91.5 & 21.3 \\
\hline Cyclohexane & $5.85 \mathrm{E}-01$ & $8.00 \mathrm{E}+00$ & $1.12 \mathrm{E}+01$ & 92.7 & 40.3 \\
\hline Chloromethane, CM, methylchloride & $3.61 \mathrm{E}-01$ & $3.60 \mathrm{E}-01$ & $1.64 \mathrm{E}+00$ & 0.2 & 354.3 \\
\hline Dichloromethane, DCM & $6.98 \mathrm{E}-02$ & $1.20 \mathrm{E}-01$ & $1.82 \mathrm{E}-01$ & 41.8 & 51.7 \\
\hline Trichloromethane, TCM, Chloroform & 7.99E-02 & $1.50 \mathrm{E}-01$ & $2.17 \mathrm{E}-01$ & 46.7 & 44.5 \\
\hline Tetrachloromethane, TeCM & 8.07E-01 & $1.20 \mathrm{E}+00$ & $1.38 \mathrm{E}+00$ & 32.7 & 14.8 \\
\hline Chloroethane, ethylchloride & $3.47 \mathrm{E}-01$ & 4.60E-01 & $6.05 \mathrm{E}+00$ & 24.6 & 1215.6 \\
\hline 1,1 - Dichloroethane, DCA & $1.70 \mathrm{E}-01$ & $2.30 \mathrm{E}-01$ & $2.86 \mathrm{E}-01$ & 26.1 & 24.4 \\
\hline 1,2 - Dichloroethane, DCA & $3.74 \mathrm{E}-02$ & $4.00 \mathrm{E}-02$ & 4.47E-01 & 6.6 & 1017.1 \\
\hline 1,1,1 - Trichloroethane, TCA & $1.61 \mathrm{E}-01$ & $7.00 \mathrm{E}-01$ & $1.46 \mathrm{E}+00$ & 76.9 & 108.7 \\
\hline 1,1,2 - Trichloroethane, TCA & $3.27 \mathrm{E}-02$ & $3.50 \mathrm{E}-02$ & $1.23 \mathrm{E}-01$ & 6.5 & 251.7 \\
\hline Chloroethene Vinyl chloride & $9.00 \mathrm{E}-01$ & $1.10 \mathrm{E}+00$ & $1.52 \mathrm{E}+02$ & 18.2 & 13732.5 \\
\hline Dichloroethene, 1,1-DCE & $6.13 \mathrm{E}-01$ & $1.10 \mathrm{E}+00$ & $7.82 \mathrm{E}+00$ & 44.2 & 611.1 \\
\hline Dichloroethene, cis - 1,2-DCE & $1.21 \mathrm{E}-01$ & $1.70 \mathrm{E}-01$ & $2.00 \mathrm{E}-01$ & 28.8 & 17.9 \\
\hline Dichloroethene, trans - 1,2-DCE & $2.70 \mathrm{E}-01$ & $3.80 \mathrm{E}-01$ & $2.74 \mathrm{E}+00$ & 28.9 & 621.0 \\
\hline Trichloroethene, TCE & $9.97 \mathrm{E}-02$ & $3.90 \mathrm{E}-01$ & $5.03 \mathrm{E}-01$ & 74.4 & 28.9 \\
\hline Tetrachloroethene, PCE & $1.06 \mathrm{E}-01$ & $7.20 \mathrm{E}-01$ & $1.19 \mathrm{E}+00$ & 85.3 & 64.8 \\
\hline & & & & $\begin{array}{c}\% \text { difference } \\
\text { (low) }\end{array}$ & $\begin{array}{c}\begin{array}{c}\text { \% difference } \\
\text { (high) }\end{array} \\
\end{array}$ \\
\hline & & & maximum & 92.7 & 13732.5 \\
\hline & & & minimum & 0.0 & 14.8 \\
\hline & & & median & 38.5 & 64.8 \\
\hline
\end{tabular}


Table S4. $\log \mathrm{K}_{\mathrm{ow}}$ ranges for organic compounds originally modeled in MOCLA.

\begin{tabular}{|c|c|c|c|c|c|}
\hline \multirow[t]{2}{*}{ Chemical } & \multicolumn{5}{|c|}{$K_{\text {ow }}\left(\log K_{\text {ow }}\right)$} \\
\hline & low & $\begin{array}{c}\text { MOCLA } \\
\text { (accepted) }\end{array}$ & high & $\begin{array}{c}\% \\
\text { difference } \\
\text { (low) }\end{array}$ & $\begin{array}{l}\text { \% difference } \\
\text { (high) }\end{array}$ \\
\hline Benzene & 1.56 & 2.10 & 2.52 & 25.7 & 20.0 \\
\hline Toluene & 1.83 & 2.70 & 3.01 & 32.2 & 11.5 \\
\hline Ethylbenzene & 2.68 & 3.10 & 3.32 & 13.5 & 7.1 \\
\hline Xylene (o) & 2.12 & 3.10 & 3.42 & 31.6 & 10.3 \\
\hline Xylene $(\mathrm{m} / \mathrm{p})$ & 3.04 & 3.20 & 3.29 & 5.0 & 2.8 \\
\hline $1,3,5$ Trimethylbenzene & 3.42 & 3.40 & 4.02 & 0.6 & 18.2 \\
\hline Phenol & 1.45 & 1.50 & 1.60 & 3.3 & 6.7 \\
\hline Cresol, (o) & 1.95 & 2.00 & 2.24 & 2.5 & 12.0 \\
\hline 2,4 - Dimethylphenol & 2.14 & 2.40 & 2.80 & 10.8 & 16.7 \\
\hline 1,2-Dichlorobenzene & 2.97 & 3.40 & 3.75 & 12.6 & 10.3 \\
\hline 1,4-Dichlorobenzene & 3.17 & 3.40 & 3.78 & 6.8 & 11.2 \\
\hline $2-$ Chlorophenol & 0.83 & 2.20 & 2.25 & 62.3 & 2.3 \\
\hline 2,4 - Dichlorophenol & 2.90 & 3.10 & 3.23 & 6.5 & 4.2 \\
\hline Naphthalene & 3.01 & 3.40 & 4.70 & 11.5 & 38.2 \\
\hline 1- Methylnaphthalene & 3.86 & 3.90 & 5.08 & 1.0 & 30.3 \\
\hline Flourene & 3.91 & 4.20 & 4.47 & 6.9 & 6.4 \\
\hline Anthracene & 3.45 & 4.40 & 4.67 & 21.6 & 6.1 \\
\hline n-Hexane & 2.90 & 4.10 & 4.25 & 29.3 & 3.7 \\
\hline n-Heptane & 3.42 & 4.60 & 4.76 & 25.7 & 3.5 \\
\hline n-Octane & 4.00 & 5.20 & 5.29 & 23.1 & 1.7 \\
\hline n-Nonane & 4.42 & 5.60 & 5.65 & 21.1 & 0.9 \\
\hline Cyclohexane & 2.40 & 3.40 & 3.70 & 29.4 & 8.8 \\
\hline Chloromethane, CM, methylchloride & 0.91 & 0.90 & 1.06 & 1.1 & 17.8 \\
\hline Dichloromethane, DCM & 1.07 & 1.30 & 1.63 & 17.7 & 25.4 \\
\hline Trichloromethane, TCM, Chloroform & 1.43 & 2.00 & 2.13 & 28.5 & 6.5 \\
\hline Tetrachloromethane, $\mathrm{TeCM}$ & 2.60 & 2.60 & 2.99 & 0.0 & 15.0 \\
\hline Chloroethane, ethylchloride & 1.20 & 1.40 & 1.55 & 14.3 & 10.7 \\
\hline 1,1 - Dichloroethane, DCA & 1.79 & 1.80 & 1.90 & 0.6 & 5.6 \\
\hline 1,2 - Dichloroethane, DCA & 1.30 & 1.50 & 1.76 & 13.3 & 17.3 \\
\hline $1,1,1$ - Trichloroethane, TCA & 2.17 & 2.50 & 2.51 & 13.2 & 0.4 \\
\hline 1,1,2 - Trichloroethane, TCA & 1.89 & 2.40 & 2.42 & 21.3 & 0.8 \\
\hline Chloroethene Vinylchloride & 0.60 & 1.00 & 1.39 & 40.0 & 39.0 \\
\hline Dichloroethene, 1,1 - DCE & 1.48 & 2.10 & 2.13 & 29.5 & 1.4 \\
\hline Dichloroethene, cis - 1,2-DCE & 1.51 & 1.90 & 1.86 & 20.5 & 2.1 \\
\hline Dichloroethene, trans - 1,2-DCE & 1.48 & 1.90 & 2.09 & 22.1 & 10.0 \\
\hline Trichloroethene, TCE & 2.28 & 2.50 & 2.61 & 8.8 & 4.4 \\
\hline Tetrachloroethene, PCE & 2.60 & 2.80 & 3.40 & 7.1 & 21.4 \\
\hline & & & \multirow{4}{*}{$\begin{array}{l}\text { maximum } \\
\text { minimum } \\
\text { median }\end{array}$} & $\begin{array}{c}\% \\
\text { difference } \\
\text { (low) } \\
\end{array}$ & $\begin{array}{c}\% \text { difference } \\
\text { (high) }\end{array}$ \\
\hline & & & & 62.3 & 39.0 \\
\hline & & & & 0.0 & 0.4 \\
\hline & & & & 13.5 & 8.8 \\
\hline
\end{tabular}


Table S5. Henry's law constant ranges for CWAs and TICs.

\begin{tabular}{|c|c|c|c|}
\hline & \multicolumn{3}{|c|}{ Henry's law constant (dimensionless) } \\
\hline & Minimum & Accepted & Maximum \\
\hline Toxic Industrial Compounds & & & \\
\hline Carbon disulfide & $3.6 \times 10^{-1}$ & $5.9 \times 10^{-1(\mathrm{a})}$ & $9.7 \times 10^{-1}$ \\
\hline Furan & $1.4 \times 10^{-1}$ & $2.2 \times 10^{-1(\mathrm{a})}$ & $3.6 \times 10^{-1}$ \\
\hline & & & \\
\hline Chemical Warfare Agents & & & \\
\hline Distilled Mustard (HD) & $6.0 \times 10^{-4}$ & $9.8 \times 10^{-4(\mathrm{a})}$ & $1.6 \times 10^{-3}$ \\
\hline Nitrogen Mustard (HN-2) & $2.1 \times 10^{-6}$ & $3.5 \times 10^{-6}$ & $5.7 \times 10^{-6}$ \\
\hline Lewisite (L) & $7.1 \times 10^{-3}$ & $1.1 \times 10^{-2(\mathrm{a})}$ & $1.9 \times 10^{-2}$ \\
\hline Ethyldichloroarsine (ED) & $1.5 \times 10^{-2}$ & $2.4 \times 10^{-2}$ & $4.0 \times 10^{-2}$ \\
\hline Phosgene Oxime (CX) & $1.4 \times 10^{-5}$ & $2.2 \times 10^{-5}$ & $3.6 \times 10^{-5}$ \\
\hline GA (Tabun) & $4.0 \times 10^{-7}$ & $6.5 \times 10^{-7(\mathrm{a})}$ & $1.1 \times 10^{-6}$ \\
\hline GB (Sarin) & $2.3 \times 10^{-4}$ & $3.8 \times 10^{-4}$ & $6.2 \times 10^{-4}$ \\
\hline GD (Soman) & $1.2 \times 10^{-4}$ & $1.9 \times 10^{-4}$ & $3.1 \times 10^{-4}$ \\
\hline GE & $3.0 \times 10^{-4}$ & $5.0 \times 10^{-4}$ & $8.2 \times 10^{-4}$ \\
\hline GF & $2.4 \times 10^{-4}$ & $3.9 \times 10^{-4}$ & $6.4 \times 10^{-4}$ \\
\hline VX & $8.8 \times 10^{-8}$ & $1.4 \times 10^{-7(\mathrm{a})}$ & $2.4 \times 10^{-7}$ \\
\hline VG & $7.1 \times 10^{-9}$ & $1.2 \times 10^{-8}$ & $1.9 \times 10^{-8}$ \\
\hline VM & $2.8 \times 10^{-8}$ & $4.5 \times 10^{-8}$ & $7.4 \times 10^{-8}$ \\
\hline CS & $2.6 \times 10^{-7}$ & $4.2 \times 10^{-7}$ & $6.9 \times 10^{-7}$ \\
\hline
\end{tabular}

${ }^{a}$ Experimentally-determined value from the literature. Accepted values without a superscript are EPISuite estimates. 
Table S6. Log $\mathrm{K}_{\mathrm{ow}}$ ranges for CWAs and TICs.

\begin{tabular}{|c|c|c|c|}
\hline & \multicolumn{3}{|c|}{ Log $_{\mathbf{0 w}}$} \\
\hline & Minimum & Accepted & Maximum \\
\hline Toxic Industrial Compounds & & & \\
\hline Carbon disulfide & 1.68 & $1.94^{\mathrm{a}}$ & 2.11 \\
\hline Furan & 1.16 & $1.34^{\mathrm{a}}$ & 1.46 \\
\hline Chemical Warfare Agents & & & \\
\hline Distilled Mustard (HD) & 2.08 & 2.41 & 2.62 \\
\hline Nitrogen Mustard (HN-2) & 0.52 & $0.60^{\mathrm{b}}$ & 0.65 \\
\hline Lewisite (L) & 2.21 & 2.56 & 2.79 \\
\hline Ethyldichloroarsine (ED) & 2.02 & 2.34 & 2.55 \\
\hline Phosgene Oxime (CX) & 0.37 & $0.42^{\mathrm{b}}$ & 0.47 \\
\hline GA (Tabun) & 0.34 & $0.39^{\mathrm{a}}$ & 0.43 \\
\hline GB (Sarin) & 0.26 & $0.30^{\mathrm{a}}$ & 0.33 \\
\hline GD (Soman) & 1.54 & $1.78^{\mathrm{a}}$ & 1.94 \\
\hline GE & 0.63 & 0.73 & 0.79 \\
\hline GF & 1.38 & 1.60 & 1.74 \\
\hline VX & 0.07 & $0.08^{\mathrm{a}, \mathrm{b}}$ & 0.09 \\
\hline VG & -0.26 & $-0.30^{\mathrm{b}}$ & -0.33 \\
\hline VM & -0.66 & $-0.77^{\mathrm{b}}$ & -0.83 \\
\hline CS & 2.39 & 2.76 & 3.00 \\
\hline
\end{tabular}

a Experimentally-determined value from the literature. Accepted values without this superscript are EPISuite estimates.

${ }^{\mathrm{b}} \log \mathrm{K}_{\mathrm{ow}}$ is equal to $\log \mathrm{K}_{\mathrm{ow}}(\mathrm{pH})$, as described in eqn. S10. $\log \mathrm{K}_{\mathrm{ow}}(\mathrm{pH})$ values were calculated at $\mathrm{pH} 7$. 
Table S7 Physical-chemical property data for CWA hydrolysates. ${ }^{a}$

\begin{tabular}{|c|c|c|c|}
\hline & $\begin{array}{l}\text { Thiodiglycol } \\
\text { (TDG) }\end{array}$ & $\begin{array}{l}\text { 2-(2-chloroethyl) } \\
\text { methylamino ethanol }\end{array}$ & $\begin{array}{c}\text { S-(2-diisopropylaminoethyl) } \\
\text { methyl phosphonothioate } \\
\text { (EA2192) }\end{array}$ \\
\hline Chemical Formula & $\mathrm{C}_{4} \mathrm{H}_{10} \mathrm{O}_{2} \mathrm{~S}$ & $\mathrm{C}_{5} \mathrm{H}_{12} \mathrm{NOCl}$ & $\mathrm{C}_{9} \mathrm{H}_{22} \mathrm{NO}_{2} \mathrm{PS}$ \\
\hline CAS number & $111-48-8$ & $51822-57-2$ & $73207-98-4$ \\
\hline Parent CWA & sulfur mustard & nitrogen mustard & VX \\
\hline $\begin{array}{l}\text { Molecular weight } \\
\quad\left(\mathrm{g} \mathrm{mol}^{-1}\right)\end{array}$ & 122.18 & 137.61 & 239.32 \\
\hline Boiling point $\left({ }^{\circ} \mathrm{C}\right)$ & $218^{\mathrm{b}}$ & $213.4^{\mathrm{b}}$ & $339.45^{\mathrm{b}}$ \\
\hline Freezing point $\left({ }^{\circ} \mathbf{C}\right)$ & $-10.2^{b}$ & $3.5^{\mathrm{b}}$ & $58.2^{\mathrm{b}}$ \\
\hline $\begin{array}{l}\text { Vapor pressure } \\
\text { (mm Hg) }\end{array}$ & $3.2 \times 10^{-3(\mathrm{~b})}$ & $0.033^{\mathrm{b}}$ & $5.1 \times 10^{-6(\mathrm{~b})}$ \\
\hline $\begin{array}{c}\text { Henry's Law constant } \\
\text { (dimensionless) } \\
\text { at } 25^{\circ} \mathrm{C}\end{array}$ & $7.6 \times 10^{-6(b)}$ & $3.4 \times 10^{-8(b)}$ & $1.8 \times 10^{-10(b)}$ \\
\hline $\log K_{\text {ow }}$ & -0.63 & $-0.19^{b}$ & $-0.4^{c}$ \\
\hline $\begin{array}{l}\text { Hydrolysis half-life } \\
\text { (min) }\end{array}$ & unavailable & unavailable & unavailable \\
\hline $\begin{array}{c}\text { Aqueous solubility } \\
\left(\mathrm{mg} \mathrm{L}^{-1}\right)\end{array}$ & $1.0 \times 10^{6}$ & $1.0 \times 10^{6(\mathrm{~b})}$ & $3.3 \times 10^{5(\mathrm{~b})}$ \\
\hline $\begin{array}{l}\text { Molecular diffusion } \\
\text { coefficient in air } \\
\quad\left(\mathrm{cm}^{2} \sec ^{-1}\right)^{\mathrm{d}}\end{array}$ & 0.081 & 0.076 & 0.055 \\
\hline $\begin{array}{l}\text { Molecular diffusion } \\
\text { coefficient in water } \\
\qquad\left(\mathrm{cm}^{2} \sec ^{-1}\right)^{\mathrm{e}}\end{array}$ & $9.6 \times 10^{-6}$ & $8.7 \times 10^{-6}$ & $6.3 \times 10^{-6}$ \\
\hline $\mathbf{p K}_{\mathrm{a}}$ & - & $7^{c}$ (tertiary amine) & $\begin{array}{c}0.9^{\mathrm{c}}(\mathrm{P}-\mathrm{OH}) \\
9.5^{\mathrm{c}}(\text { tertiary amine })\end{array}$ \\
\hline
\end{tabular}

${ }^{a}$ Data compiled from the following sources: $(10,35,37,45) ;{ }^{b}$ Estimated with EPI Suite v.3.12 (40); ${ }^{\mathrm{c}}$ Estimated using Chem-Silico software (44), the $\log \mathrm{K}_{\mathrm{ow}}$ value for EA2192 is estimated for the zwitterionic form at $\mathrm{pH} 7{ }^{\mathrm{d}}$ Estimated using Wilke-Lee equation (42); ${ }^{\mathrm{e}}$ Estimated using Hayduk-Laudie equation (42). 
Table S8. Predicted fate routes for base-case scenario after one year with no biodegradation $\left(\lambda_{\text {biotic }}=\infty\right)$.

\begin{tabular}{|c|c|c|c|c|c|c|c|}
\hline \multirow[b]{2}{*}{ Chemical Agent } & \multicolumn{7}{|c|}{ Fate routes (no degradation) } \\
\hline & $\begin{array}{c}\text { Fraction } \\
\text { remaining }\end{array}$ & $\begin{array}{c}\mathrm{F}_{\mathrm{a}} \\
\text { (gas phase } \\
\text { advection) }\end{array}$ & \begin{tabular}{l}
\multicolumn{1}{c}{$\mathbf{F}_{\text {gd }}$} \\
(gas phase \\
diffusion)
\end{tabular} & $\begin{array}{c}F_{w} \\
\text { (aqueous } \\
\text { transport) }\end{array}$ & $\begin{array}{c}F_{\lambda} \\
\text { (biotic) }\end{array}$ & $\begin{array}{c}\mathbf{F}_{\lambda} \\
\text { (abiotic) }\end{array}$ & $\begin{array}{c}\mathbf{F}_{\text {diff }} \\
\text { (liner) }\end{array}$ \\
\hline \multicolumn{8}{|c|}{ Toxic Industrial Compounds } \\
\hline Carbon disulfide & 0.812 & 0.188 & 0.000 & 0.000 & 0.000 & 0.000 & 0.000 \\
\hline Furan & 0.811 & 0.188 & 0.000 & 0.000 & 0.000 & 0.000 & 0.000 \\
\hline \multicolumn{8}{|c|}{ Chemical Warfare Agents } \\
\hline Distilled Mustard & 0.000 & 0.000 & 0.000 & 0.000 & 0.000 & 1.000 & 0.000 \\
\hline Nitrogen Mustard & 0.000 & 0.000 & 0.000 & 0.000 & 0.000 & 1.000 & 0.000 \\
\hline Lewisite & 0.000 & 0.000 & 0.000 & 0.000 & 0.000 & 1.000 & 0.000 \\
\hline Ethyldichloro-arsine & 0.000 & 0.000 & 0.000 & 0.000 & 0.000 & 1.000 & 0.000 \\
\hline Phosgene Oxime & 0.842 & 0.000 & 0.000 & 0.002 & 0.000 & 0.156 & 0.000 \\
\hline GA (Tabun) & 0.000 & 0.000 & 0.000 & 0.000 & 0.000 & 1.000 & 0.000 \\
\hline GB (Sarin) & 0.000 & 0.000 & 0.000 & 0.000 & 0.000 & 1.000 & 0.000 \\
\hline GD (Soman) & 0.531 & 0.000 & 0.000 & 0.000 & 0.000 & 0.468 & 0.000 \\
\hline $\mathrm{GE}$ & 0.006 & 0.000 & 0.000 & 0.000 & 0.000 & 0.994 & 0.000 \\
\hline GF & 0.286 & 0.000 & 0.000 & 0.000 & 0.000 & 0.713 & 0.000 \\
\hline VX & 0.440 & 0.000 & 0.000 & 0.002 & 0.000 & 0.557 & 0.000 \\
\hline $\mathrm{VG}$ & 0.241 & 0.000 & 0.000 & 0.003 & 0.000 & 0.755 & 0.000 \\
\hline VM & 0.075 & 0.000 & 0.000 & 0.004 & 0.000 & 0.921 & 0.000 \\
\hline $\mathrm{CS}$ & 0.000 & 0.000 & 0.000 & 0.000 & 0.000 & 1.000 & 0.000 \\
\hline
\end{tabular}


Table S9. Predicted fate routes for base-case scenario after one year with $\lambda_{\text {biotic }}=1000$ days.

\begin{tabular}{|c|c|c|c|c|c|c|c|}
\hline \multirow[b]{2}{*}{ Chemical Agent } & \multicolumn{7}{|c|}{ Fate routes $\left(\lambda_{\text {biotic }}=1000\right.$ days $)$} \\
\hline & $\begin{array}{l}\text { Fraction } \\
\text { remaining }\end{array}$ & $\begin{array}{c}\mathbf{F}_{\mathrm{a}} \\
\text { (gas phase } \\
\text { advection) }\end{array}$ & $\begin{array}{c}\mathbf{F}_{\mathrm{gd}} \\
\text { (gas phase } \\
\text { diffusion) } \\
\end{array}$ & $\begin{array}{c}F_{w} \\
\text { (aqueous } \\
\text { transport) } \\
\end{array}$ & $\begin{array}{c}\mathbf{F}_{\lambda} \\
\text { (biotic) }\end{array}$ & $\begin{array}{c}\mathbf{F}_{\lambda} \\
\text { (abiotic) }\end{array}$ & $\begin{array}{c}\mathbf{F}_{\text {diff }} \\
\text { (liner) }\end{array}$ \\
\hline \multicolumn{8}{|l|}{$\begin{array}{l}\text { Toxic Industrial } \\
\text { Compounds }\end{array}$} \\
\hline Carbon disulfide & 0.811 & 0.188 & 0.000 & 0.000 & 0.001 & 0.000 & 0.000 \\
\hline Furan & 0.809 & 0.188 & 0.000 & 0.000 & 0.003 & 0.000 & 0.000 \\
\hline \multicolumn{8}{|c|}{ Chemical Warfare Agents } \\
\hline Distilled Mustard & 0.000 & 0.000 & 0.000 & 0.000 & 0.000 & 1.000 & 0.000 \\
\hline Nitrogen Mustard & 0.000 & 0.000 & 0.000 & 0.000 & 0.001 & 0.999 & 0.000 \\
\hline Lewisite & 0.000 & 0.000 & 0.000 & 0.000 & 0.000 & 1.000 & 0.000 \\
\hline Ethyldichloroarsine & 0.000 & 0.000 & 0.000 & 0.000 & 0.000 & 1.000 & 0.000 \\
\hline Phosgene Oxime & 0.830 & 0.000 & 0.000 & 0.002 & 0.013 & 0.155 & 0.000 \\
\hline GA (Tabun) & 0.000 & 0.000 & 0.000 & 0.000 & 0.001 & 0.999 & 0.000 \\
\hline GB (Sarin) & 0.000 & 0.000 & 0.000 & 0.000 & 0.002 & 0.998 & 0.000 \\
\hline GD (Soman) & 0.531 & 0.000 & 0.000 & 0.000 & 0.001 & 0.468 & 0.000 \\
\hline GE & 0.006 & 0.000 & 0.000 & 0.000 & 0.002 & 0.992 & 0.000 \\
\hline GF & 0.286 & 0.000 & 0.000 & 0.000 & 0.001 & 0.713 & 0.000 \\
\hline $\mathrm{VX}$ & 0.430 & 0.000 & 0.000 & 0.002 & 0.016 & 0.552 & 0.000 \\
\hline $\mathrm{VG}$ & 0.232 & 0.000 & 0.000 & 0.003 & 0.022 & 0.743 & 0.000 \\
\hline VM & 0.069 & 0.000 & 0.000 & 0.003 & 0.027 & 0.900 & 0.000 \\
\hline $\mathrm{CS}$ & 0.000 & 0.000 & 0.000 & 0.000 & 0.000 & 1.000 & 0.000 \\
\hline
\end{tabular}


Table S10. Predicted fate routes for base-case scenario after one year with $\lambda_{\text {biotic }}=100$ days.

\begin{tabular}{|c|c|c|c|c|c|c|c|}
\hline \multirow[b]{2}{*}{ Chemical Agent } & \multicolumn{7}{|c|}{ Fate routes $\left(\lambda_{\text {biotic }}=100\right.$ days $)$} \\
\hline & $\begin{array}{l}\text { Fraction } \\
\text { remaining }\end{array}$ & $\begin{array}{c}\mathrm{F}_{\mathrm{a}} \\
\text { (gas phase } \\
\text { advection) }\end{array}$ & $\begin{array}{c}F_{\text {gd }} \\
\text { (gas phase } \\
\text { diffusion) }\end{array}$ & $\begin{array}{c}\mathrm{F}_{\mathrm{w}} \\
\text { (aqueous } \\
\text { transport) }\end{array}$ & $\begin{array}{c}\mathbf{F}_{\lambda} \\
\text { (biotic) }\end{array}$ & $\underset{\text { (abiotic) }}{\mathbf{F}_{\lambda}}$ & $\begin{array}{c}\mathbf{F}_{\text {diff }} \\
\text { (liner) }\end{array}$ \\
\hline \multicolumn{8}{|c|}{ Toxic Industrial Compounds } \\
\hline Carbon disulfide & 0.802 & 0.187 & 0.000 & 0.000 & 0.011 & 0.000 & 0.000 \\
\hline Furan & 0.786 & 0.185 & 0.000 & 0.000 & 0.029 & 0.000 & 0.000 \\
\hline \multicolumn{8}{|c|}{ Chemical Warfare Agents } \\
\hline Distilled Mustard & 0.000 & 0.000 & 0.000 & 0.000 & 0.000 & 1.000 & 0.000 \\
\hline Nitrogen Mustard & 0.000 & 0.000 & 0.000 & 0.000 & 0.005 & 0.995 & 0.000 \\
\hline Lewisite & 0.000 & 0.000 & 0.000 & 0.000 & 0.000 & 1.000 & 0.000 \\
\hline Ethyldichloroarsine & 0.000 & 0.000 & 0.000 & 0.000 & 0.000 & 1.000 & 0.000 \\
\hline Phosgene Oxime & 0.206 & 0.000 & 0.000 & 0.002 & 0.121 & 0.146 & 0.000 \\
\hline GA (Tabun) & 0.000 & 0.000 & 0.000 & 0.000 & 0.009 & 0.991 & 0.000 \\
\hline GB (Sarin) & 0.000 & 0.000 & 0.000 & 0.000 & 0.016 & 0.984 & 0.000 \\
\hline GD (Soman) & 0.523 & 0.000 & 0.000 & 0.000 & 0.012 & 0.465 & 0.000 \\
\hline $\mathrm{GE}$ & 0.005 & 0.000 & 0.000 & 0.000 & 0.017 & 0.978 & 0.000 \\
\hline GF & 0.280 & 0.000 & 0.000 & 0.000 & 0.012 & 0.707 & 0.000 \\
\hline VX & 0.346 & 0.000 & 0.000 & 0.002 & 0.148 & 0.503 & 0.000 \\
\hline VG & 0.159 & 0.000 & 0.000 & 0.003 & 0.191 & 0.647 & 0.000 \\
\hline $\mathrm{VM}$ & 0.035 & 0.000 & 0.000 & 0.003 & 0.219 & 0.743 & 0.000 \\
\hline $\mathrm{CS}$ & 0.000 & 0.000 & 0.000 & 0.000 & 0.000 & 1.000 & 0.000 \\
\hline
\end{tabular}


Table S11. Predicted fate routes for base-case scenario after one year with $\lambda_{\text {biotic }}=10$ days.

\begin{tabular}{|c|c|c|c|c|c|c|c|}
\hline \multirow[b]{2}{*}{ Chemical Agent } & \multicolumn{7}{|c|}{ Fate routes $\left(\lambda_{\text {biotic }}=10\right.$ days $)$} \\
\hline & $\begin{array}{l}\text { Fraction } \\
\text { remaining }\end{array}$ & $\begin{array}{c}\mathrm{F}_{\mathrm{a}} \\
\text { (gas phase } \\
\text { advection) } \\
\end{array}$ & $\begin{array}{c}\mathbf{F}_{\mathrm{gd}} \\
\text { (gas phase } \\
\text { diffusion) } \\
\end{array}$ & $\begin{array}{c}F_{w} \\
\text { (aqueous } \\
\text { transport) } \\
\end{array}$ & $\begin{array}{c}\mathbf{F}_{\lambda} \\
\text { (biotic) }\end{array}$ & $\begin{array}{c}\mathbf{F}_{\lambda} \\
\text { (abiotic) }\end{array}$ & $\begin{array}{c}\mathbf{F}_{\text {diff }} \\
\text { (liner) }\end{array}$ \\
\hline \multicolumn{8}{|c|}{ Toxic Industrial Compounds } \\
\hline Carbon disulfide & 0.720 & 0.177 & 0.000 & 0.000 & 0.103 & 0.000 & 0.000 \\
\hline Furan & 0.587 & 0.162 & 0.000 & 0.000 & 0.250 & 0.000 & 0.000 \\
\hline \multicolumn{8}{|c|}{ Chemical Warfare Agents } \\
\hline Distilled Mustard & 0.000 & 0.000 & 0.000 & 0.000 & 0.001 & 0.999 & 0.000 \\
\hline Nitrogen Mustard & 0.000 & 0.000 & 0.000 & 0.000 & 0.044 & 0.956 & 0.000 \\
\hline Lewisite & 0.000 & 0.000 & 0.000 & 0.000 & 0.000 & 1.000 & 0.000 \\
\hline Ethyldichloroarsine & 0.000 & 0.000 & 0.000 & 0.000 & 0.000 & 1.000 & 0.000 \\
\hline Phosgene Oxime & 0.206 & 0.000 & 0.000 & 0.001 & 0.708 & 0.085 & 0.000 \\
\hline GA (Tabun) & 0.000 & 0.000 & 0.000 & 0.000 & 0.080 & 0.919 & 0.000 \\
\hline GB (Sarin) & 0.000 & 0.000 & 0.000 & 0.000 & 0.138 & 0.862 & 0.000 \\
\hline GD (Soman) & 0.454 & 0.000 & 0.000 & 0.000 & 0.109 & 0.437 & 0.000 \\
\hline GE & 0.002 & 0.000 & 0.000 & 0.000 & 0.145 & 0.852 & 0.000 \\
\hline GF & 0.232 & 0.000 & 0.000 & 0.000 & 0.112 & 0.657 & 0.000 \\
\hline $\mathrm{VX}$ & 0.040 & 0.000 & 0.000 & 0.001 & 0.717 & 0.243 & 0.000 \\
\hline VG & 0.004 & 0.000 & 0.000 & 0.001 & 0.743 & 0.252 & 0.000 \\
\hline $\mathrm{VM}$ & 0.000 & 0.000 & 0.000 & 0.001 & 0.746 & 0.253 & 0.000 \\
\hline $\mathrm{CS}$ & 0.000 & 0.000 & 0.000 & 0.000 & 0.001 & 0.999 & 0.000 \\
\hline
\end{tabular}




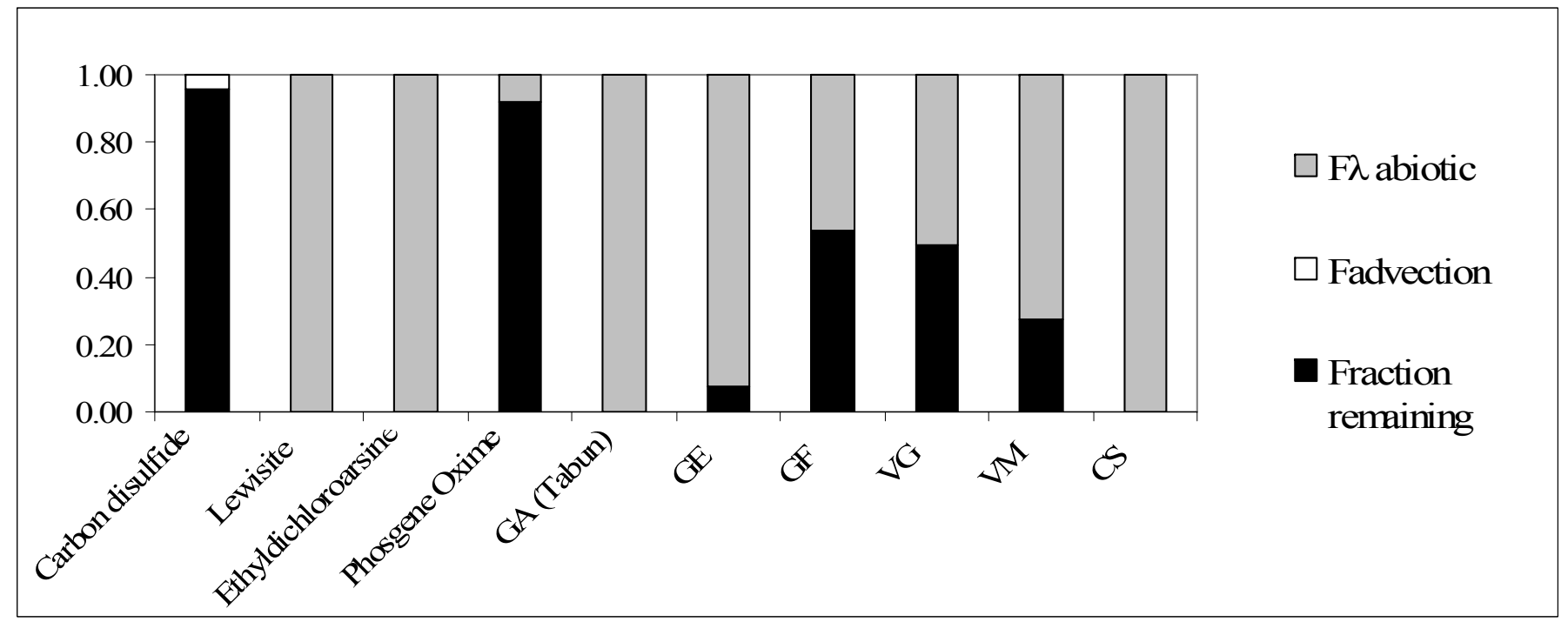

Figure S1. Fate routes for carbon disulfide and the remaining CWAs after six months (arid scenario). The fraction of chemical transported via all other fate pathways was less than $1 \%$.

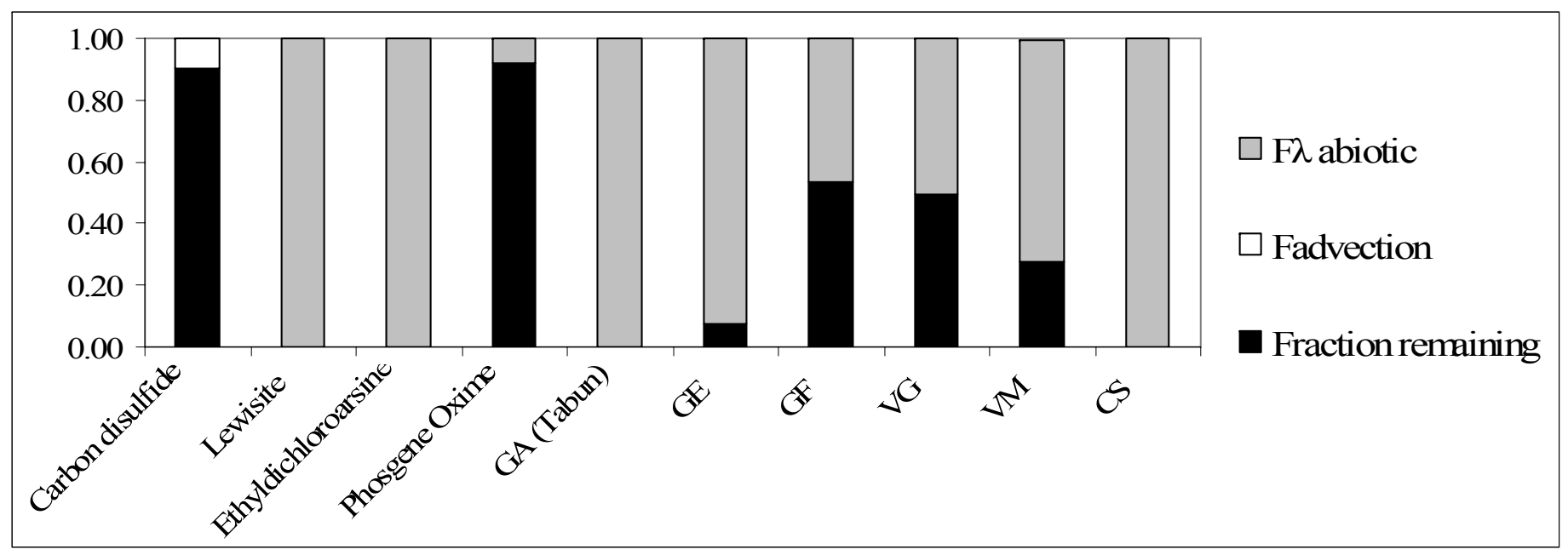

Figure S2. Fate routes for carbon disulfide and the remaining CWAs after six months (wet scenario). The fraction of chemical transported via all other fate pathways was less than $1 \%$. 


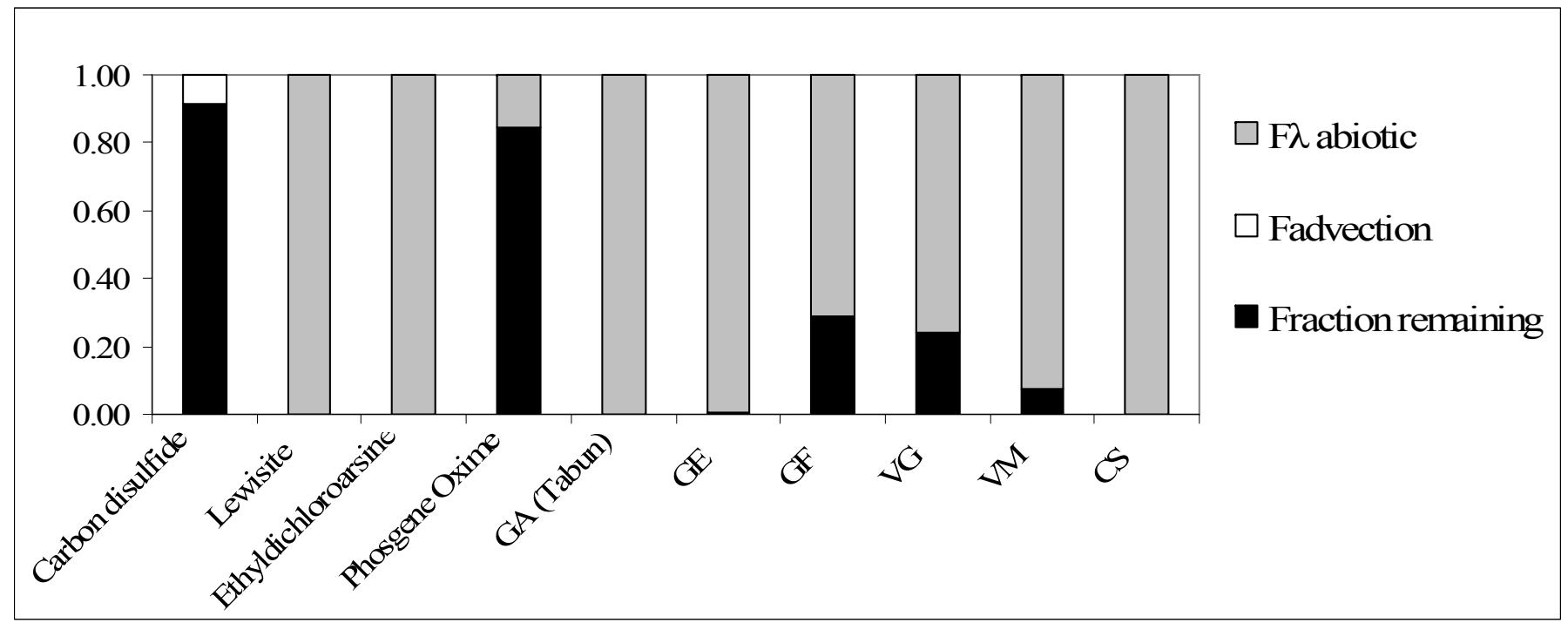

Figure S3. Fate routes for carbon disulfide and the remaining CWAs after one year (arid scenario). The fraction of chemical transported via all other fate pathways was less than $1 \%$.

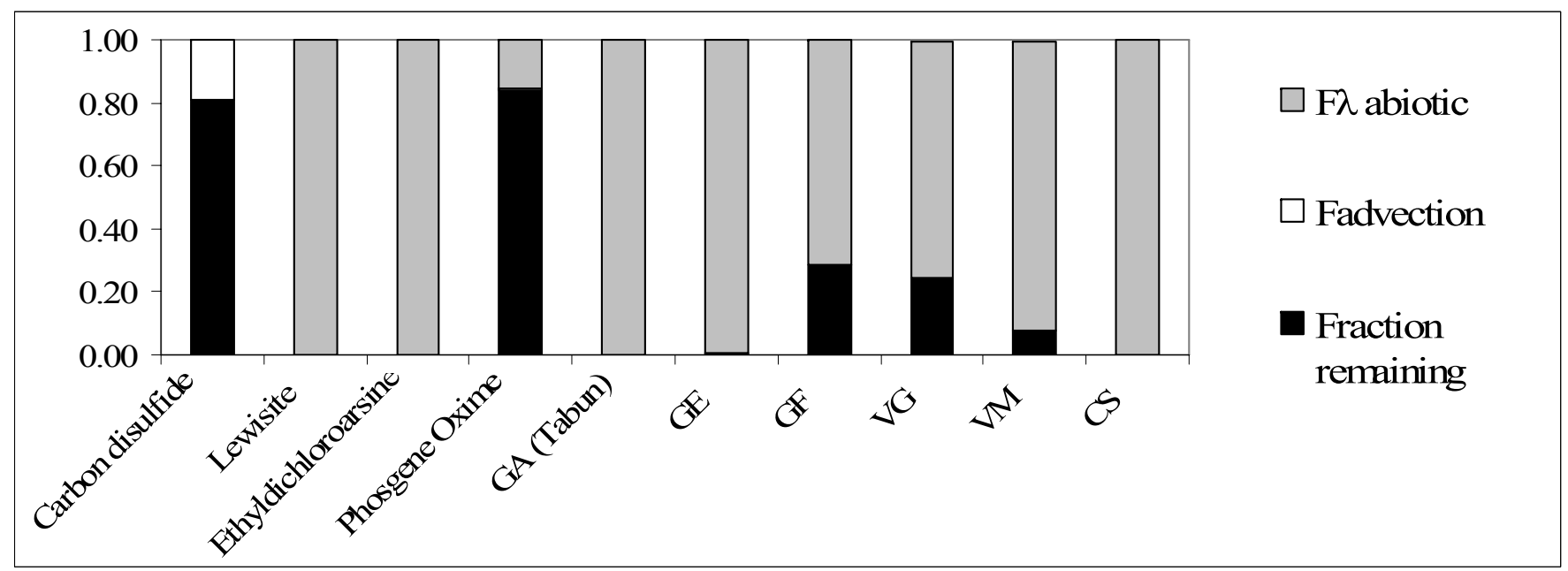

Figure S4. Fate routes for carbon disulfide and the remaining CWAs after one year (wet scenario). The fraction of chemical transported via all other fate pathways was less than $1 \%$. 


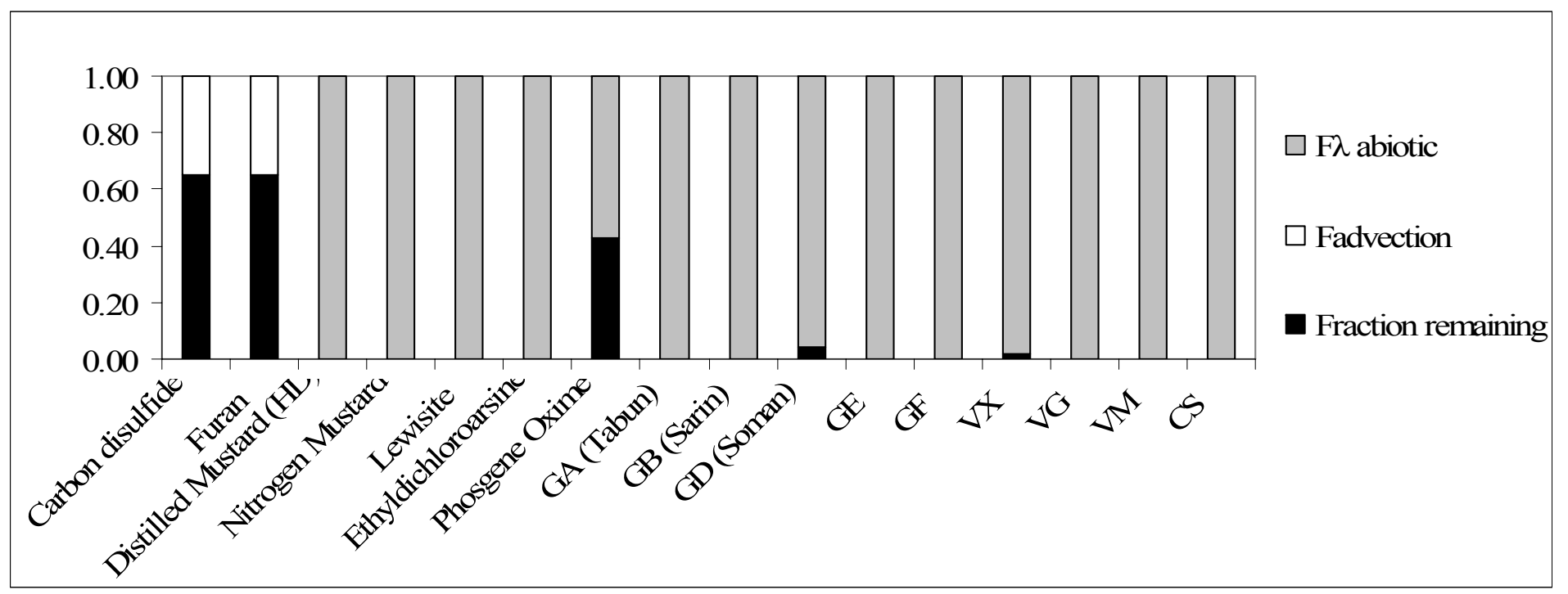

Figure S5. Fate routes for the TICs and CWAs after five years (arid scenario). The fraction of chemical transported via all other fate pathways was less than $1 \%$.

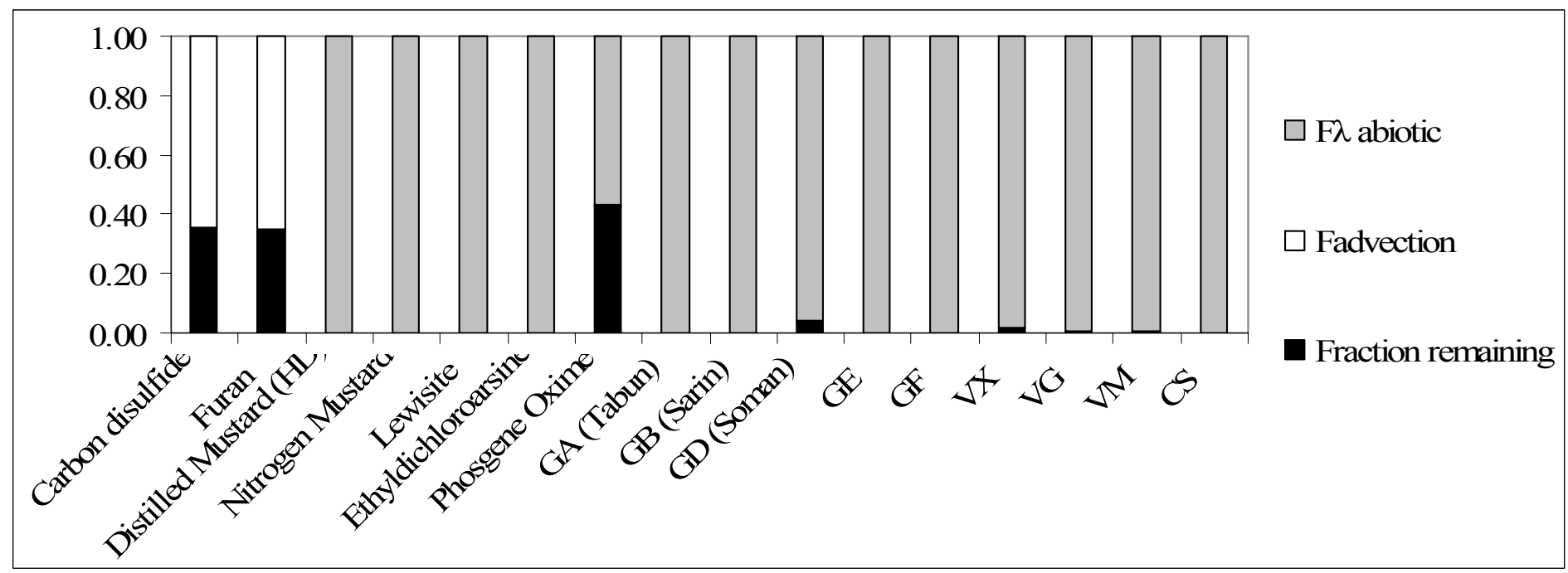

Figure S6. Fate routes for the TICs and CWAs after five years (wet scenario). The fraction of chemical transported via all other fate pathways was less than $1 \%$. 


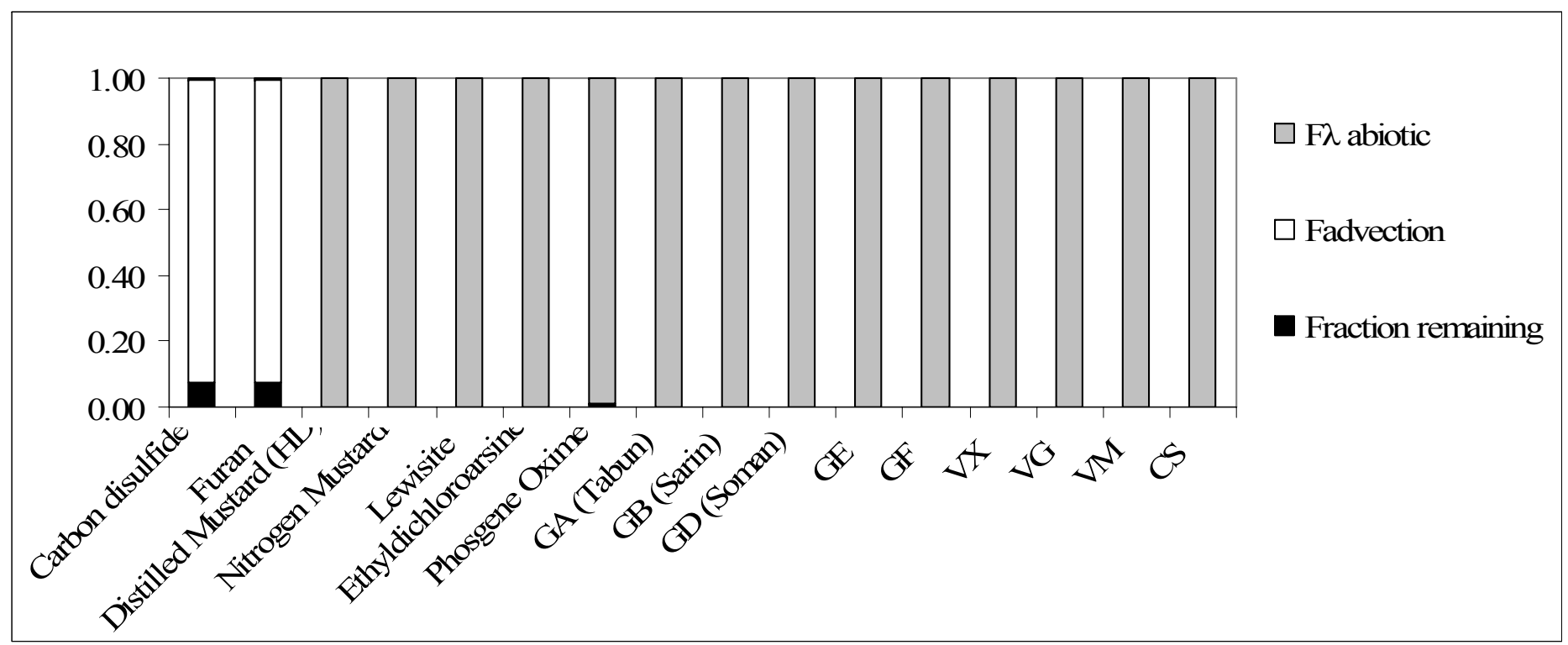

Figure S7. Fate routes for the TICs and CWAs after thirty years (arid scenario). The fraction of chemical transported via all other fate pathways was less than $1 \%$.

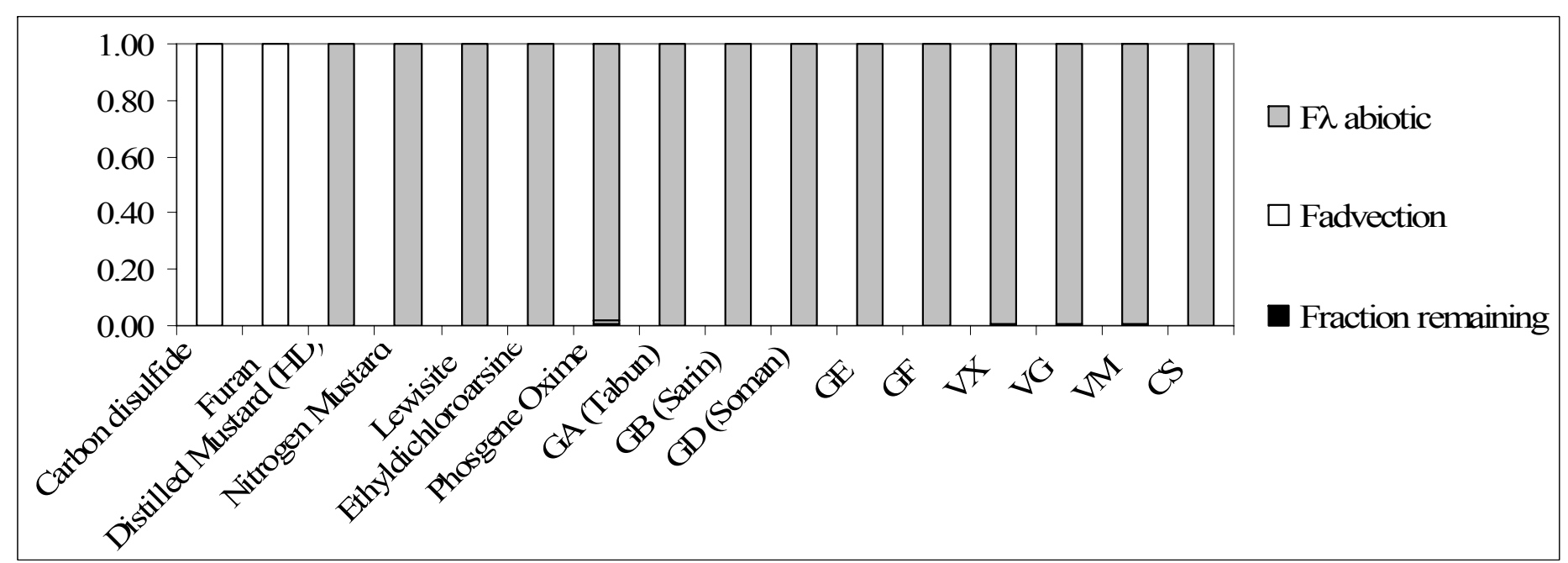

Figure S8. Fate routes for the TICs and CWAs after thirty years (wet scenario). The fraction of chemical transported via all other fate pathways was less than $1 \%$. 


\section{Literature Cited}

(1) Somani, S. M., ed., Chemical Warfare Agents. Academic Press, Inc.: San Diego, CA, 1 1992.

(2) Department of the Army. Potential Military Chemical/Biological Agents and Compounds; FM 3-9, NAVFAC P-467, AFR 355-7; Headquarters, Department of the Army, Navy and Air Force: Fort McClellan, AL, 2005.

(3) Kingery, A. F.; Allen, H. E. The environmental fate of organophosphorus nerve agents: A review. Toxicol. Environ. Chem. 1995, 47, 155-184.

(4) Reinhart, D. R.; Gould, J. P.; Cross, W. H.; Pohland, F. G., Sorptive behavior of selected organic pollutants codisposed in a municipal landfill. In Emerging Technologies in Hazardous Waste, ACS Symposium Series; American Chemical Society: 1990; 422, 292-310.

(5) Ejlertsson, J.; Johansson, E.; Karlson, A.; Meyerson, U.; Svensson, B. H. Anaerobic degradation of xenobiotics by organisms from municipal solid waste landfilling conditions. Antonie van Leeuwenhoek 1996, 69, 67-74.

(6) Ejlertsson, J.; Meyerson, U.; Svensson, B. H. Anaerobic degradation of phthalic acid esters during digestion of municipal solid waste under landfilling conditions. Biodegradation 1996, 7, 345-352.

(7) Sanin, F.; Knappe, D. R. U.; Barlaz, M. A. Biodegradation and humification of toluene in a simulated landfill. Water Res. 2000, 34, (12), 3063-3074.

(8) Wu, B.; Taylor, C. M.; Knappe, D. R. U.; Nanny, M. A.; Barlaz, M. A. Factors controlling alkylbenzene sorption to municipal solid waste. Environ. Sci. Technol. 2001, 35, 4569-4576.

(9) Franke, S., Textbook of Military Chemistry, Vol. 1; USAMIIA-HT-039-82, AD B062913; Defense Technical Information Center: Alexandria, VA, 1982.

(10) Munro, N. B.; Talmage, S. S.; Griffin, G. D.; Waters, L. C.; Watson, A. P.; King, J. F.; Hauschild, V. The sources, fate and toxicity of chemical warfare agent degradation products. Environ. Health Perspect. 1999, 107, 933-974.

(11) Cohen, B. Chemical Warfare Agents and Related Chemical Problems Parts III-IV; Summary Technical Report Division 9; NRDC Office of Science Research and Development, 1946.

(12) Morrill, L. G.; Reed, L. W.; Chinn, K. S. K. Toxic Chemicals in the Soil Environment: Volume 2. Interactions of some toxic chemicals/chemical warfare agents and soils; TECOM Project 2-CO-210-049; Oklahoma State University, Stillwater, OK, 1985.

(13) Rosenblatt, D. H.; Miller, T. A.; Dacre, J. C.; Muul, I.; Cogley, D. R. Problem Definition Studies on Potential Environmental Pollutants II. Physical, Chemical, Toxicological and Biological Properties of 16 Substances; Tech Rpt. 7509; AD A030428; U.S. Army Medical Bioengineering Research and Development Laboratory: Fort Detrick, MD, 1975.

(14) Clark, D. N. Review of reactions of chemical agents in water; AD-A213 287; Defense Technical Information Center: Alexandria, VA, 1989.

(15) Harvey, S. P.; Szafraniec, L. L.; Beaudry, W. T.; Earley, J. T.; Irvine, R. L., Neutralization and biodegradation of sulfur mustard; ERDEC-TR-388; U.S. Army Munitions Chemical Command: Aberdeen Proving Grounds, MD 1997. 
(16) Epstein, J.; Rosenblatt, D.; Gallacio, A.; McTeague, W. Summary Report on a Data Base for Predicting Consequences of Chemical Disposal Operations; EASP 1200-12; Department of the Army Headquarters: Edgewood Arsenal, MD, 1973.

(17) Christensen, T.H.; Kjeldsen, P.; Albrechtsen, H.-J.; Heron, G.; Nielsen, P.H.; Bjerg, P.L.; Holm, P.E. Attenuation of landfill leachate pollutants in aquifers. Crit. Rev. Environ. Sci. Technol. 1994, 24, 119-202.

(18) Hilger, H.H.; Barlaz, M.A. Anaerobic decomposition of refuse in landfills and methane oxidation of cover soils. In Manual of Environmental Microbiology, $2^{\text {nd }} e d$., 2001; pp. 696-718.

(19) Barlaz, M.A. Carbon storage during biodegradation of municipal solid waste components in laboratory-scale landfills. Global Biogeochem. Cycles. 1998, 12, 373-380.

(20) Escher, B.I.; Schwarzenbach, R.P. Partitioning of substituted phenols in liposome-water, biomembrane-water, and octanol-water systems. Environ. Sci. Technol. 1996, 30, 260270.

(21) Skylar, V. I.; Mosolova, T. P.; Kucherenko, I. A.; Degtyarova, N. N.; Varfolomeyev, S. D.; Kalyuzhyi, S. V. Anaerobic toxicity and biodegradability of hydrolysis products of chemical warfare agents. Appl. Biochem. Biotechnol. 1999, 81, 107-117.

(22) Park, J. K.; Nibras, M. Mass flux of organic chemicals through polyethylene geomembranes. Water Environ. Res. 1993, 65, 227-237.

(23) Millington, R.J. Gas diffusion in porous media. Science 1959, 130, 100-102.

(24) Johnson, P. C.; Ettinger, R.A. Heuristic model for predicting the intrusion rate of contaminant vapors into buildings. Environ. Sci Technol. 1991, 25, 1445-1452.

(25) Bendz, D.; Singh, V.P.; Rosqvist, H.; Bengtsson, L. Kinematic wave model for water movement in municipal solid waste. Water Resour. Res. 1998, 34, 2963-2970.

(26) Barlaz, M.A. Carbon storage during biodegradation of municipal solid waste components in laboratory-scale landfills. Global Biogeochem. Cycles. 1998, 12, 373-380.

(27) Camobreco, V.; Repa, E.; Ham, R. K.; Barlaz, M. A.; Felker, M.; Rousseau, C.; ClarkBalbo, M.; Rathle, J.; Thorneloe, S. Life Cycle Inventory of a Modern Municipal Solid Waste Landfill; Environmental Research and Education Foundation: Washington, D.C., 2000.

(28) U.S. Environmental Protection Agency. User's Manual Landfill Gas Emissions Model (Version 2.0); EPA/600/R-98/054; U.S. EPA: Research Triangle Park, NC, 1998.

(29) U.S. Environmental Protection Agency. Standards of performance for new stationary sources and guidelines for control of existing sources: municipal solid waste landfills. Code of Federal Regulations. Title 40. Sections 9, 51, 52, and 60; Fed. Regist. 1996, 61. Code of Federal Regulations; 40 Parts 257 and 258; 1991.

Benson, C. H.; Daniel, D.E.; Boutwell, G.P. Field performance of compacted clay liners. J. Geotech. Geoenviron. Eng. 1999, 125, 390-402.

Daubert, T. E.; Danner, R. P. Physical and Thermodynamic Properties of Pure Chemicals Data Compilation; Taylor and Francis: Washington, D.C., 1989.

Elliot, S., The solubility of carbon disulfide vapor in natural aqueous systems. Atmos. Environ. 1989, 23, 977-1980.

Goldman, M.; Dacre, J. C. Lewisite - Its Chemistry, Toxicology and Biological Effects. Rev. Environ. Contam. Toxicol. 1989, 110, 75-115.

Hansch, C.; Leo, A.; Hoekman, D., Exploring QSAR: Hydrophobic, Electronic, and Steric Constants; American Chemical Society: 1995. 
(36) Valvani, S. C.; Yalkowsky, S. H.; Roseman, T. J. Solubility and partitioning. 4. Aqueous solubility and octanol-water partition coefficients of liquid non-electrolytes. J. Pharm. Sci. 1981, 70, 502-507.

(37) Yalkowsky, S. H.; He, Y. Handbook of Aqueous Solubility Data; CRC Press: 2003.

(38) Yaws, C. L., Handbook of Vapor Pressure; Gulf Publishing Company: Houston, Texas, 1994.

(39) World Health Organization. Epidemic and Pandemic Alert and Response (EPR). 2005. http://www.who.int/csr/delibepidemics/biochemguide/en/index.html.

(40) U.S. Environmental Protection Agency. Estimation Program Interface (EPI) Suite, August 17, 2004; http:/www.epa.gov/opptintr/exposure/docs/episuite.htm.

(41) Mitretek Systems. Chemistry of Lewisite. 2004. http://www.mitretek.org/home.nsf/homelandsecurity/Lewisite.

(42) Lyman, W. J.; Reehl, W. F.; Rosenblatt, D. H. Handbook of Chemical Property Estimation Methods: Environmental Behavior of Organic Compounds. American Chemical Society: Washington D.C., 1990.

(43) Kurtz, A.P; D'Silva, T.D.J. Estimation of dissociation constants ( $\mathrm{pK}_{\mathrm{a}}$ 's) of oximes from proton chemical shifts in dimethyl sulfoxide solution. J. Pharm. Sci. 1987, 76, 599-610.

(44) Chemsilico, LLC. Chemsilico Product Secure Site. 2003. https://secure.chemsilico.com/index.php.

(45) Small, M. J. Compounds formed from the chemical decontamination of HD, GB, VX and their environmental fate; Technical Report 8304; U.S. Army Medical Bioengineering Research and Development Laboratory: Fort Detrick, MD, 1984. 